\title{
Biochemical Changes of Cubiu Fruits (Solanum sessiliflorum Dunal, Solanaceae) According to Different Tissue Portions and Ripening Stages
}

\author{
Moacir Couto de Andrade Júnior ${ }^{1,2 *}$, Jerusa Souza Andrade1,2, Suely de Souza Costa ${ }^{3}$ \\ ${ }^{1}$ Post-Graduation Department, Universidade Nilton Lins, Manaus, Brazil \\ ${ }^{2}$ Department of Food Technology, Instituto Nacional de Pesquisas da Amazônia (INPA), Manaus, Brazil \\ ${ }^{3}$ Department of Agricultural Sciences, Instituto Nacional de Pesquisas da Amazônia (INPA), Manaus, Brazil \\ Email: *moacircoutjr@gmail.com
}

How to cite this paper: de Andrade Júnior, M.C., Andrade, J.S. and de Souza Costa, S. (2016) Biochemical Changes of Cubiu Fruits (Solanum sessiliflorum Dunal, Solanaceae) According to Different Tissue Portions and Ripening Stages. Food and Nutrition Sciences, 7, 1191-1219.

http://dx.doi.org/10.4236/fns.2016.712111

Received: October 1, 2016

Accepted: October 28, 2016

Published: October 31, 2016

Copyright $\odot 2016$ by authors and Scientific Research Publishing Inc. This work is licensed under the Creative Commons Attribution International License (CC BY 4.0).

http://creativecommons.org/licenses/by/4.0/

(c) (i) Open Access

\begin{abstract}
Cubiu fruits (Solanum sessiliflorum Dunal, Solanaceae) are known for their high nutritional value and low caloric content. This work aimed at evaluating biochemical indices of cubiu fruits according to different tissues (peel, pulp and placenta) and ripening stages (green, turning, ripe and fully ripe). The fruits were randomly harvested to investigate sensory aspects (colorimetry, blanching effect, pigments) and biochemical indices (moisture and dry matter, Total Soluble Solids (TSS), pH, Titratable Acidity (TA), TSS/TA ratio, ascorbic acid, Alcohol-Insoluble Solids (AIS), pectinesterase activity and pectin content). The analyses were performed at the laboratory of Instituto Nacional de Pesquisas da Amazônia (INPA), Manaus, Brazil. The blanching process preserved pulp colors at all ripening stages. Chlorophylls were higher in green peels; flavonoids and carotenoids, in fully ripe peels. Anthocyanins were entirely absent. Pulp (turning fruits) showed the highest moisture content (91.05), followed by ripe pulp (90.70) and fully ripe pulp (90.62). Pulp TSS changed little whereas placenta TSS declined and were associated with increased TA and $\mathrm{pH}$ reduction (fully ripe fruits). Pulp $\mathrm{pH}$ and TA varied little whereas placenta $\mathrm{pH}$ was notably low and TA was remarkably high (fully ripe fruits). Pulp TSS/TA ratio showed predominance of TSS while in placenta, there was predominance of organic acids. AIS, precursors of pectin, were stable during ripening. The statistical analysis of dietary fiber content showed one modal value in the AIS. In pulp, pectinesterase activity correlated inversely with pectin content. Cubiu fruits were significant sources of bioactive compounds, e.g. chlorophylls, flavonoids and carotenoids, predominantly in the peel and the pulp; soluble functional fibers, e.g. pectin $(g / 100 \mathrm{~g}$ fresh
\end{abstract}


weight), particularly in the green peel (1.00) and the fully ripe pulp (1.12), and other versatile molecules, e.g. ascorbic acid ( $\mathrm{mg} / 100 \mathrm{~g}$ fresh weight), especially in the fully ripe peel (32.45) and placenta (24.84) and the turning placenta (21.27). Cubiu fruits are rich in ascorbic acid and should be included in the human diet.

\section{Keywords}

Cocona, Fruit Placenta, Medicinal Plant, Pectinesterase Activity, Vitamin C

\section{Introduction}

The human population of the Amazonian region has long used fruits from a species of the Solanaceae family commonly referred to as cubiu (Solanum sessiliflorum Dunal) in Brazil, cocona in Colombia and Peru and tupiru in Venezuela [1] [2]. Cubiu herbaceous plants have drawn the attention of researchers for their biological versatility (preferential heliophilous or facultative ombrophilous plants), their capacity to grow in upland or lowland areas, their climacteric (ethylene-dependent) as well as non-climacteric (ethylene-independent) behavior (depending on the cultivar or the genotype) and the good technological quality of their fruits for the food industry [1] [3] [4] [5].

Cubiu fruits are made up by the endocarp (also called placenta), a soft-textured (jelly-like) tissue that fills out the whole locular cavity and by the harder-textured surrounding pulp (or mesocarp), with a variable thickness proportional to the size of the fruit [6]. Similar to other Solanaceae fruits (e.g. tomatoes), cubiu seeds are numerous and embedded in the locular tissue [2] [7]. The cubiu fruit peel (or exocarp) constitutes a thin layer that is, however, resistant to digital compression and to peel. All these tissue portions are edible and technologically profitable, i.e. they may give rise to new food products of excellent quality and deserve further investigation.

In fact, all the different tissue portions of cubiu fruits (i.e. peel, pulp and placenta) have already been successfully used for the preparation of high-quality foods such as dehydrated peels, palatable juices, hypocaloric jellies, among other delicatessens, although the pulp has been studied more extensively for its broader commercial interest, as in the present work (Figure 1) [3] [8].

Cubiu is considered as a significant fruit to the Amazonian diet and is characterized as a nutrient-dense (e.g. minerals, soluble fibers such as pectin), low-calorie fruit [6]. However, little remains known about the biochemical changes of cubiu fruits according to different tissue portions, e.g. in the fruit peel, regarding pigments, i.e. colorimetry, chlorophylls ( $a, b$ and total), total flavonoids and anthocyanins, total carotenoids; in the fruit pulp, i.e. the effects of grinding and blanching on color changes, dietary fibers (Alcohol-Insoluble Solids or AIS and pectin) and pectinesterase activity; in the pulp and the placenta of the fruits, i.e. Total Soluble Solids (TSS), pH, Titratable Acidity (TA), TSS/TA ratio; in the three tissue portions, i.e. moisture and dry matter, the aforementioned 


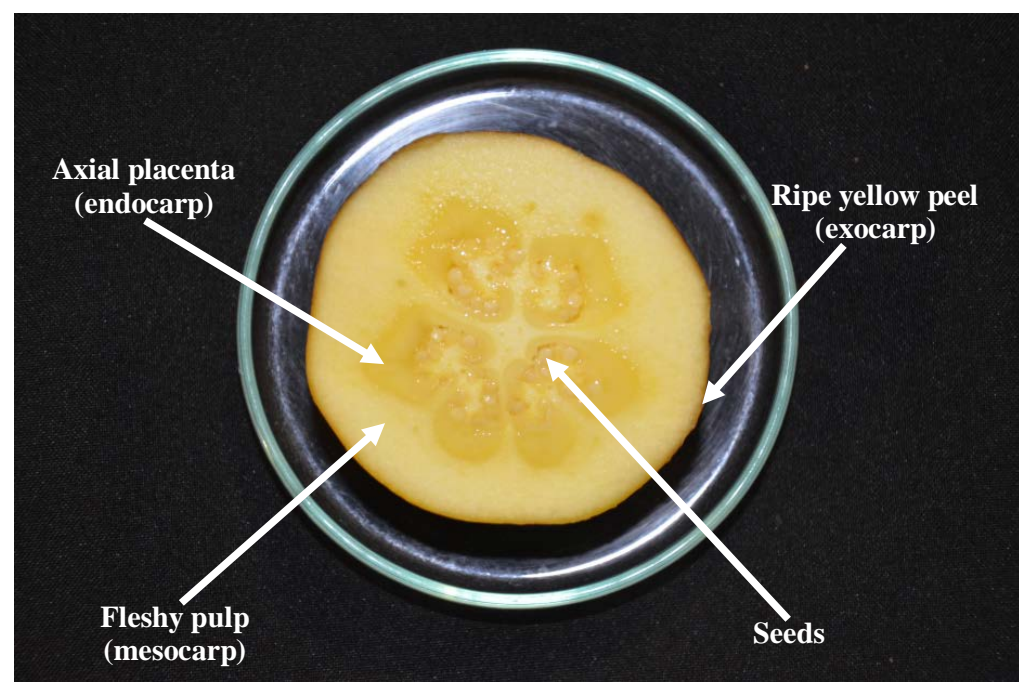

Figure 1. Transverse section of ripe cubiu fruit with histological details. Note: The histological structure of cubiu fruit does not greatly change during ripening, making it always possible for a suitable tissue separation and utilization. However, from the green fruit stage to that of ripe fruit, the colors of the internal structures change from the light citrine yellow to the more pronounced yellow. As further discussed with regard to cubiu, color modifications are equally related to the changes in the pigment content of the fruit tissues.

pigments (except chlorophylls), ascorbic acid (or vitamin C), AIS and pectin. Nevertheless, it is first imperative to review the main concepts and features of these biochemical indices in order to grasp their relevance in the ripening process of cubiu fruits.

Fruit ripening is a complex, genetically programmed process, resulting in remarkable changes in the color, texture, flavor and aroma of the fruit [9]. Fruit pigments are the chemicals responsible for the peel and flesh color and during the ripening process, many fruits undergo significant changes in their pigment composition [10] [11]. These changes include both the degradation of existing pigments and the synthesis of new pigments (in many cases, both processes occur simultaneously) [10]. The fruit color usually changes from green (associated with elevated chlorophyll content) to yellow or red (associated with the degradation of chlorophyll structure and the synthesis and/or revelation of existing carotenoids) or yet red-purple (associated with anthocyanins, capable of masking carotenoid and chlorophyll content) [10] [11] [12].

Plant leaves are the primary photosynthetic organs responsible for the conversion of carbon dioxide and water to carbohydrate and oxygen by using solar energy [13]. Chlorophylls $a$ and $b$ enable light harvesting for photosynthesis, while carotenoids (carotenes and xanthophylls) and anthocyanins afford protection from excess light, e.g. during leaf development or abiotic stress [14]. However, non-foliar photosynthesis may be regarded as an important strategy of additional carbon-acquisition (while chlorophyllous stems or aerial roots can even serve as primary photosynthetic organs, reproductive structures can derive up to $60 \%$ of their total carbon requirement from own carbon dioxide fixation) [15]. In addition, for certain fruits, e.g. olives (Olea spp., Oleaceae), which remain green for a long period (with their chloroplasts active even when 
changes in pigmentation occur), photosynthesis is a secondary source of sugars for the fruits themselves [16].

Cubiu fruits exhibit distinctive colors according to the four ripening stages described as patterns by the Brazilian Amazonian population [1] [17]. At the initial ripening stage, the fruit surface is completely green and shiny. At the turning stage of ripening, the fruit surface is mid green, turning to lighting green or greenish-yellow. At the ripe stage, the fruit surface is completely yellow and shiny. At the fully ripe stage, the fruit surface is deeply colored red wine. Nonetheless, this description is not categorical and the ripening fruits may present many intermediate colors. Hence, colorimetric accuracy is important. Albeit the biochemical basis of cubiu fruit colors during ripening remained unknown until the present work. As the natives of the Brazilian Amazonia consume cubiu fruits at all ripening stages, the fruit peel color aids them in the judgment of the best culinary use. For instance, whole cubiu fruits at the green and turning stages are suitable for the preparation of fish stews. The pulp of ripe (or fully ripe) cubiu fruits is suitable for the preparation of jellies and other delicacies. As cubiu placenta is very acidic, it is used to season fish instead of lemon (Citrus limon (L.) Osbeck, Rutaceae).

Importantly, when fresh cubiu fruits are peeled and the tissues are exposed to air, they are quickly brown (no matter the ripening stage). Fruit tissue browning may be actually the result of cellular breakdown, leading to the mixing of browning-related enzymes and their substrates, which results in (enzymatic) oxidation in the presence of oxygen [18]. After mechanical cutting, phenols release also represents a deleterious effect as these compounds become high-affinity substrates for browning-related enzymes and cubiu fruits are rich in phenols [6] [19]. Therefore, fruit tissue browning is a multifactorial process that can be divided into two major types: the enzymatic browning (especially including peroxidase (EC 1.11.1.7) and polyphenol oxidase (EC 1.10.3.1) activity) and the non-enzymatic browning (comprising the Maillard reaction, caramelization, ascorbic acid browning, among others) [19] [20]. However, because plant peroxidases are glycosylated proteins, peroxidase is thought to be the most heat stable enzyme in plants and it is also assumed that if peroxidase is destroyed, it is highly probable that other enzymes involved in reactions leading to quality deterioration will, likewise, have been inactivated [21] [22] [23].

There are several methods employed in the prevention of enzymatic browning. These methods can be applied during the processing (e.g. hot water blanching, freezing $\left(-18^{\circ} \mathrm{C}\right)$, irradiation) and as inhibitors targeted towards the enzyme substrates (e.g. ascorbic acid as a reducing agent) [20]. Ascorbic acid effectively plays a complex role throughout the browning process. It can both inhibit polyphenol oxidase (as a chelating agent) and promote browning (in the presence of amino acids) [20]. Apart from these potential detrimental effects on fruit appearance, ascorbic acid is highly beneficial for human health (e.g. antioxidant function, collagen formation, carnitine synthesis, neurotransmitter synthesis, detoxification, formation of cholesterol to bile acids, iron $\left(\mathrm{Fe}^{3+}\right.$ $\left.\rightarrow \mathrm{Fe}^{2+}\right)$ and copper $\left(\mathrm{Cu}^{2+} \rightarrow \mathrm{Cu}^{+}\right)$absorption, corticosteroid synthesis) [24]. Until the 
present work, ascorbic acid changes remained unknown in cubiu fruit tissues at different ripening stages. Furthermore, the potential human health benefits of plant pigments such as chlorophylls (e.g. cancer prevention via antioxidant and antimutagenic activities), carotenoids (including vitamin A precursors, e.g. $\beta$-carotene) and anthocyanins (e.g. antioxidant activity and neuroprotection), raise scientific interest and deserve further investigation [1] [25] [26].

Also, the amount of moisture is one of the most fundamental analytical procedures that can be performed on a food product; the dry matter that remains after moisture removal being commonly referred to as total solids [1]. TSS are especially used as indicators of total sugar content in fruits, providing information on the fruit maturation state; on the other hand, they are formed by water-soluble compounds such as organic acids, ascorbic acid and pectin [27] [28]. TSS are the most important quality parameters used to indicate sweetness of fresh and processed horticultural food products not only in laboratories for research, but also by industry to determine marketing standards [28]. The $\mathrm{pH}$ and the TA are affected by multiple factors, for instance, plant species, variety, genotype, environmental factors, growing conditions, ripening stages, time of harvest and postharvest treatments and storage [29]. In sum, TSS and TA as well as TSS/TA ratio are the common quality indicators used to determine sweetness, tartness of a fruit juice and degree of maturity of the fruits from which the juice was extracted, respectively [30]. As ascorbic acid is the least stable of all vitamins and it can be easily degraded during processing and storage, its content is taken as an indication of fruit freshness, retention of other compounds and a quality indicator for shelf life, especially for citrus-derived products [31] [32].

Pectinesterase (EC 3.1.1.11) is one of the main enzymes involved in the breakdown of pectin [17]. Pectin is a hetero-polysaccharide predominantly containing galacturonic acid residues, in which varying proportions of the acid groups are present as methoxyl esters, while a certain amount of neutral sugars might be present as side chains [17] [33]. Studying pectinesterase activity and pectin content in cubiu pulp will clarify their role in the softening process of the fruit during ripening. Thus, the aim of this work was to evaluate the aforesaid biochemical indices of cubiu fruits according to different tissue portions (peel, pulp and placenta) and ripening stages (green, turning, ripe and fully ripe).

\section{Materials and Methods}

\subsection{Cubiu Fruit Sample Preparation}

Cubiu fruits were randomly and manually harvested from herbaceous plants grown in low humic gley soil at the experimental farm of Universidade Federal do Amazonas (UFAM) in the municipality of Manaus, Brazil $\left(2^{\circ} 39^{\prime} 1.98^{\prime \prime}\right.$ south and $60^{\circ} 3^{\prime} 18.41^{\prime \prime}$ west, $67 \mathrm{~m}$ altitude). The determination of the ripening stages (green, turning, ripe and fully ripe) for the fruits was based on the four-color pattern described by the Amazonian population of Brazil (as previously detailed in the introduction of the present study) (Figure 2). In addition to those standard colors, a supplementary criterion for 


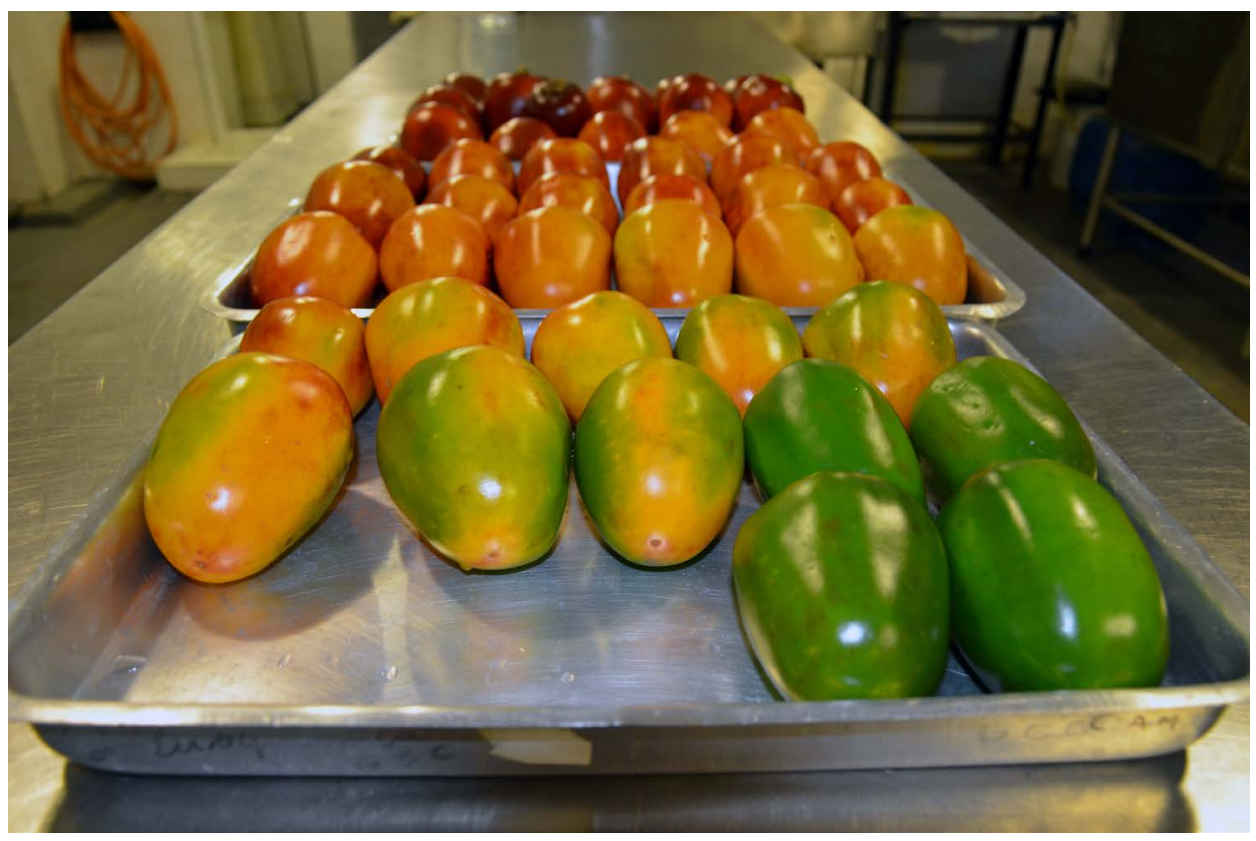

Figure 2. Sub-sample of the 118 cubiu fruits herein studied at four ripening stages. Note: Cubiu fruits are exuberantly polychrome. It is, however, easy to distinguish the standard green stage (first sighted fruits on the stainless tray) from the turning stage (greenish-yellow fruits) or yet the typical ripe stage (completely yellow fruits) from the fully ripe stage (deeply colored red fruits on the last tray). As noted before, this description is not categorical and the ripening fruits may present many intermediate colors; hence the need for colorimetry to obtain accurate data.

the inclusion of the fruits in this study was their structural integrity (i.e. absence of injuries). After harvest, the fruits were transported in plastic containers to the laboratory (Instituto Nacional de Pesquisas da Amazônia-INPA) where the peels were washed and dried with paper towel at ambient temperature $\left(22^{\circ} \mathrm{C}\right)$. The sample size $(n=118)$ of whole cubiu fruits at four ripening stages (the independent variables of this study) included 41 green fruits, 26 turning fruits, 29 ripe fruits and 22 fully ripe fruits. The peel color of each fruit was determined by colorimetry (subsection 2.2.). Subsequently, the fruit tissue portions (peel, pulp and placenta) at the four ripening stages were carefully separated (subsection 2.3.) and homogenized in the blender (BLSTVB-RVO-000, Oster, USA). Mostly important blender parameters comprise the rotational speed (28.000 $\mathrm{rpm})$, the electric motor power $(1.400 \mathrm{~W})$ and the pitcher size $(2 \mathrm{~L})$. Part of the homogenized material was immediately used for enzyme extraction as well as the determination of pectinesterase activity and other analyses (moisture and dry matter, $\mathrm{pH}, \mathrm{TA}$, TSS, TSS/TA ratio, ascorbic acid), pigment extraction (chlorophylls, total flavonoids and anthocyanins, total carotenoids), representing dependent variables to this study. The remaining part of the homogenized material was stored in polyethylene bags and kept in a freezer $\left(-20^{\circ} \mathrm{C}\right)$ until use in the analyses of other dependent variables of this study (i.e. AIS and pectin). Also, three fruits of each ripening stage were separated to study the blanching effect on pulp coloration (subsection 2.4.). Three replicates were prepared from each sample. 


\subsection{Colorimetry of Cubiu Peels}

The fruit peel color was determined, using a Konica Minolta portable colorimeter (CR400, Kyoto, Japan). The colorimeter was adjusted with a white standard calibration plate before use [34]. Three measurements were made in the equatorial region of each fruit. The colorimeter described color in three coordinates established by the CIE (Commission Internationale $d$ Éclairage): $\mathrm{L}^{*}$, lightness, from 0 (black) to 100 (white); $\mathrm{a}^{\star}$, from -60 (green) to 60 (red); and $\mathrm{b}^{\star}$, from -60 (blue) to 60 (yellow) [34] [35]. Chroma, or the intensity of a given hue, was calculated as follows: $\left[\left(a^{\star 2}+b^{* 2}\right)^{1 / 2}\right][35]$ [36] [37] [38]. The hue angle $\left(h^{\circ}\right)$ was calculated as follows: $h^{\circ}=b^{\star} / a^{*}[35]$.

\subsection{Pulping of Cubiu Fruits}

Each fruit was cut transversely with a stainless steel knife so that the seeds were preserved. Fruit tissue portions were manually separated. The pulp adhered to the peel was carefully removed with a spatula. As other Solanaceae species, cubiu fruits present an axial placentation that facilitates the removal of this tissue portion [2].

\subsection{Blanching Effect on Cubiu Pulp}

Blanching is usually done at a specific temperature range $\left(70^{\circ} \mathrm{C}-100^{\circ} \mathrm{C}\right)$ for a specific time frame (1 - 11 minutes) [39] [40]. Three cubiu fruits of each ripening stage underwent pulping (subsection 2.3.). Cubiu pulps were cut to small pieces. Part of the sliced pulps was immediately ground in the blender for 2 minutes, forming a pasty material, then spread on four Petri dishes according to each ripening stage and photographed for later sensory analysis (control process). The remaining sliced pulps were immersed in boiling water (i.e. hot water blanching) with constant temperature control $\left(98.5^{\circ} \mathrm{C}\right)$ for $1,2,3,4,5$ and 6 minutes. After blanching, the samples were immediately cooled in an ice-water bath for 2 minutes and ground in the blender for 2 minutes, forming a pasty material, then spread on Petri dishes according to each ripening stage and photographed for subsequent sensory analysis (intervention process).

\subsection{Enzyme Extraction from Cubiu Pulp}

The preparation of the enzyme extracts was similar to the method previously described for sweet bell peppers (Capsicum annuum L., Solanaceae) [17] [41]. The enzyme extracts were prepared from $100 \mathrm{~g}$ of cubiu pulps of each studied ripening stage. Cubiu pulps were diced and homogenized in $100 \mathrm{~mL}$ of distilled and deionized water at $4^{\circ} \mathrm{C}$ for 1 minute in the blender. The resultant homogenate was filtered through nylon (pore size $0.45 \mu \mathrm{m}$ ) and the residue was resuspended in $100 \mathrm{~mL}$ of a $1 \mathrm{M} \mathrm{NaCl}$ solution at $4^{\circ} \mathrm{C}$ and then further broken up with a mortar and pestle that were also cooled to $4^{\circ} \mathrm{C}$. The resulting suspension was adjusted to $\mathrm{pH} 6.0$ using a $1 \mathrm{M} \mathrm{NaOH}$ solution and the $\mathrm{pH}$ meter Quimis (0400RS, São Paulo, Brazil). After incubation (with stirring) at $4^{\circ} \mathrm{C}$ for 1 hour, the solution was clarified by filtration through nylon (pore size $0.45 \mu \mathrm{m}$ ) and centrifugation (SL-703, SOLAB, Piracicaba, Brazil) at $15.000 \mathrm{rpm}$ for 15 minutes at $4^{\circ} \mathrm{C}$. The resultant supernatant was used for pectinesterase activity analysis. 


\subsection{Pectinesterase Activity in Cubiu Pulp}

As previously described [17], pectinesterase activity can be assayed based on the release of either free carboxyl groups $(-\mathrm{COOH})$ or methanol $\left(\mathrm{CH}_{3} \mathrm{OH}\right)$ from pectin. The most common technique is to measure the rate of release of $-\mathrm{COOH}$ from pectin (as in this work) using the $\mathrm{pH}$ stat described above. Fifty $\mathrm{mL}$ aliquots of $1.0 \%$ citric pectin (Sigma-Aldrich Inc., St. Louis, USA) diluted in a $0.1 \mathrm{M} \mathrm{NaCl}$ solution were used as substrates. The reaction was conducted under a controlled temperature range $\left(29^{\circ} \mathrm{C}\right.$ $30^{\circ} \mathrm{C}$ ) with constant stirring. Immediately after adjusting the $\mathrm{pH}$ to the narrow range of 6.99 - 7.00 using $\mathrm{NaOH}$, the enzyme extract $(2 \mathrm{~mL})$ was added to the incubation mixture over a period of 30 minutes, which allowed for titration with a $0.025 \mathrm{M} \mathrm{NaOH}$ solution. The pectin de-esterification was complete when the $\mathrm{pH}$ underwent no further change. In parallel, a control experiment was performed with enzyme extract that was heat-inactivated by immersion in boiling water $\left(98^{\circ} \mathrm{C}\right)$ for 5 minutes followed by immediate immersion in an ice-water bath. The pectinesterase activity was then calculated. The pectinesterase unit was considered to be the amount of enzyme capable of catalyzing the release of $1 \mu \mathrm{mol}$ of $-\mathrm{COOH}$ per $\mathrm{g}$ of fruit tissue portion (pulp) per 1 minute.

\subsection{Moisture and Dry Matter of Cubiu Fruit Tissues}

According to methodology previously described [1], freshly harvested cubiu fruits were homogenized in the blender and immediately kept in a furnace at $65^{\circ} \mathrm{C}$ until constant weight was reached ( 12 hours). The dry matter was estimated by difference.

\subsection{The pH and Titratable Acidity (TA) of Cubiu Pulp and Placenta}

The $\mathrm{pH}$ was measured using the calibrated $\mathrm{pH}$ meter. The determination of the TA was performed by titration with $0.1 \mathrm{M} \mathrm{NaOH}$ using phenolphthalein as the indicator [17]. The results were expressed as the percentage of citric acid [17].

\subsection{Total Soluble Solids (TSS) of Cubiu Pulp and Placenta}

TSS were measured in drops of undiluted juice from freshly harvested cubiu fruits, using a digital Reichert refractometer (AR200, New York, USA). The TSS/TA ratio was also calculated.

\subsection{Ascorbic Acid of Cubiu Fruit Tissues}

In accordance with previous methodology [42], with modifications, ascorbic acid was extracted from the three tissue portions of cubiu fruits at the four ripening stages herein studied, using $2 \mathrm{~g}$ of each sample previously homogenized. After the addition of approximately $50 \mathrm{~mL}$ of $0.5 \%$ oxalic acid solution, $100 \mathrm{mg}$ of diatomaceous earth, vortex stirring for 30 seconds, filtration through filter paper ( $3 \mu \mathrm{m}$ pores) and successive washings with $0.5 \%$ oxalic acid solution, the volume was ascertained to be $50 \mathrm{~mL}$ with $0.5 \%$ oxalic acid. Ascorbic acid was determined in test tubes containing $1 \mathrm{~mL}$ of the tissue extract samples (and $1 \mathrm{~mL}$ of oxalic acid in the blank), $3 \mathrm{~mL}$ of $0.5 \%$ oxalic acid 
solution, 3 drops of 2,6-dichlorophenolindophenol (or DPI), $1 \mathrm{~mL}$ of 2\% 2,4-dinitrophenylhydrazine (or DNPH) in $9 \mathrm{~N} \mathrm{H}_{2} \mathrm{SO}_{4}$ and 1 drop of $2.5 \%$ alcoholic thiourea solution. Each test tube was heated in a water bath $\left(100^{\circ} \mathrm{C}\right)$ for 10 minutes and subsequently cooled in an ice bath, then slowly added by $5 \mathrm{~mL}$ of $85 \% \mathrm{H}_{2} \mathrm{SO}_{4}$. At the same time, a standard curve was made using ascorbic acid (Nuclear, Diadema, Brazil). The test tubes were put at rest for 15 minutes and then were vortexed again for homogenization of their content; the absorbances read at $520 \mathrm{~nm}$ in the spectrophotometer (U T60, PG Instruments Ltd., Leicestershire, United Kingdom). The results were expressed in mg of total ascorbic acid per $100 \mathrm{~g}$ of fresh tissue portion.

\subsection{Pigment Extraction}

Light is essential for photosynthesis, yet it may be potentially harmful to plants too [43]. Thus, for this study, all pigment extraction procedures were performed in a dim environment, with protected laboratory glass works (e.g. separator funnels wrapped in aluminium foils).

\subsubsection{Chlorophylls of Cubiu Peels}

According to established methodology for the extraction of chlorophylls [44] [45] [46], $10 \mathrm{~g}$ aliquots of cubiu peel for each studied ripening stage were homogenized in the blender with $100 \mathrm{~mL}$ of aqueous $80 \%$ acetone solution (80:20, acetone/distilled water, $\mathrm{v} / \mathrm{v}$ ) and $0.5 \mathrm{~g}$ of $\mathrm{CaCO}_{3}$ for 2 minutes. The homogenate was filtered through filter paper ( $3 \mu \mathrm{m}$ pores) and added to the remaining material in the blender and dragged using $50 \mathrm{~mL}$ of aqueous $80 \%$ acetone solution and then continuing the filtration by supplementing the volume to $150 \mathrm{~mL}$ with aqueous $80 \%$ acetone solution. If the aspect of the chlorophyll solution became milky, it should be kept in a refrigerator for 1 - 2 hours before being read on the spectrophotometer at 645, 652 and $663 \mathrm{~nm}$. The results were calculated and expressed in $\mathrm{mg} / \mathrm{L}$ of chlorophylls ( $a, b$ and total) in the fruit peels.

\subsubsection{Total Flavonoids and Anthocyanins of Cubiu Fruit Tissues}

Total flavonoids and anthocyanins were determined by weighing $1 \mathrm{~g}$ of each homogenized cubiu sample and adding $40 \mathrm{~mL}$ of ethanol- $\mathrm{HCl}$ solution (this solution was prepared from ethanol (95\%) plus hydrochloric acid solution $(1.5 \mathrm{~N})$, in which $31.1 \mathrm{~mL}$ was pipetted and the volume was completed to $250 \mathrm{~mL}$ with distilled water) [47] [48]. The preparation of the ethanol- $\mathrm{HCl}$ solution was done at a ratio of 85:15 (v/v). The samples were further homogenized with a glass rod in beakers $(50 \mathrm{~mL})$ for \pm 1 minute in $40 \mathrm{~mL}$ of acidified alcohol and kept in the refrigerator for 24 hours, after which it was filtered through filter paper ( $3 \mu \mathrm{m}$ pores) to the volumetric flask, and the volume completed to $100 \mathrm{~mL}$. Samples of total flavonoids and anthocyanins were read at 374 and $535 \mathrm{~nm}$, respectively, in the above described spectrophotometer, using distilled water as blank.

\subsubsection{Total Carotenoids of Cubiu Fruit Tissues}

Total carotenoids (water-insoluble pigments) were extracted with isopropanol (30 $\mathrm{mL})$, 
hexane $(20 \mathrm{~mL})$ and sufficient distilled water to remove other pigments (e.g. hydrosoluble flavonoids); the washed hexane solution (with carotenoids) being dried and its absorbance being read at $450 \mathrm{~nm}$ on the spectrophotometer (acetone $(5 \mathrm{~mL}$ ) and hexane (45 mL) as blank in the same solvent volume) [1].

\subsection{Determination of Alcohol-Insoluble Solids (AIS) in Cubiu Fruit Tissues}

The AIS content was determined for $10 \mathrm{~g}$ aliquots of the three tissue portions [17]. Previously homogenized cubiu pulps were added to $100 \mathrm{~mL}$ of alcohol (92.8\%) and this mixture was kept immersed and thermally stabilized at $85^{\circ} \mathrm{C}$ for 20 minutes. The mixture was then immediately filtered through paper (with a known dry weight) while still hot. The residual material on the filter paper was consecutively washed with $300 \mathrm{~mL}$ of alcohol and $100 \mathrm{~mL}$ of hexane (both chemicals were purchased from Vetec, Rio de Janeiro, Brazil). The residue on the filter paper was dried at $65^{\circ} \mathrm{C}$ in a furnace equipped with an air circulation system until a constant weight was reached. The resultant dry material (AIS) was crushed with a mortar and pestle until it turned into a light-brown powder that was easily granulated at ambient temperature $\left(22^{\circ} \mathrm{C}\right)$. To minimize the uptake of moisture, the AIS samples were stored in desiccators (Laborglas, São Paulo, Brazil). The AIS content was expressed in $\mathrm{g} / 100 \mathrm{~g}$ fresh weight.

\subsection{Pectin Content in Cubiu Fruit Tissues}

The pectin content was determined from AIS $(10 \mathrm{mg})$ as previously outlined [17]. The samples were digested with $2 \mathrm{~mL}$ of concentrated $\mathrm{H}_{2} \mathrm{SO}_{4}(d=1.84)$ in an ice bath and then $50 \mathrm{~mL}$ of deionized water was slowly added over approximately 1 hour. The pectin concentration of the clear solution containing the digested sample was analyzed, using the m-hydroxydiphenyl method, and was expressed as anhydrogalacturonic acid. The absorbance was evaluated at $520 \mathrm{~nm}$ on the spectrophotometer. The pectin concentration was expressed in $\mathrm{g} / 100 \mathrm{~g}$ fresh weight.

\subsection{Statistical Analyses}

In this study, the experiments were conducted in a completely randomized design, comprising three tissue portions of cubiu fruits (peel, pulp and placenta) at four ripening stages (green, turning, ripe and fully ripe) and using three replicates from each sample. Initially, analysis of variance (ANOVA) was performed for each of the variables, which were verified by the $\mathrm{F}$ test and in case of differences, also by the Tukey test (both tests with $5 \%$ probability). Subsequently, the Pearson correlation $(\mathrm{p}<0.05)$ was performed between variables.

\section{Results and Discussion}

\subsection{Colorimetry of Cubiu Peels}

Colorimetry allows for accurate characterization of the colors of the fruits. The proper quantification of tristimulus colorimetry data is based upon trigonometric functions 
and inverse functions [35]. The results of the colorimetry of cubiu peels are detailed in Table 1. Of all the above calculated coordinates, $\mathrm{L}^{*}$ refers to the brightness (variable from 0 or black to 100 or white) and is the only measure that can be correctly and directly described without any manipulation [35]. The turning and ripe fruits were brighter ( 60.9 and 60.3 , respectively) due to the shades of yellow, in fact, confirmed by positive $b^{\star}$ (57.3 and 60.8, respectively) [37]. The green and turning fruits presented negative values $(-18.6$ and -3.0 , respectively) due to the marked predominance of green color [37]. When the coordinates $\mathrm{a}^{*}$ and $\mathrm{b}^{\star}$ were converted to $\mathrm{C}^{\star}$ and $\mathrm{h}^{\circ}$, they presented high values, considering the vivid character of the colors, allowing to speak of "vivid yellow-green" (57.4) for the turning fruits, of "vivid yellow" (64.4) for the ripe fruits [35] [37]. The $\mathrm{L}^{*}$ of the ripe fruits was lower due in part to the positive value for red (24.4) [37]. These results do not entirely apply to other cubiu cultivars due to their great phenotypic variation (e.g. color, morphology) [1].

\subsection{Blanching Effect on Cubiu Pulp}

Blanching procedures vary with every fruit and should, therefore, be standardized [40]. As described above, hot water blanching $\left(98.5^{\circ} \mathrm{C}\right)$ was tested on cubiu pulps for $1,2,3$, 4, 5 and 6 minutes. Cubiu pulps that were not blanched (control process) did not resist browning in less than 2 minutes of homogenization in the blender. In contrast, cubiu pulps subjected to blanching for 6 minutes (intervention process) resisted browning after blender homogenization and maintained their characteristic colors for 24 hours at ambient temperature $\left(22^{\circ} \mathrm{C}\right)$ - Figure 3.

Hot water blanching is certainly the most popular and commercially used blanching method, with the additional advantages of simplicity, controllability, microbial content reduction and economy (although prolonged hot water blanching results in considerable loss of water-soluble nutrients such as proteins, minerals, vitamins, sugars and decomposition of pectic substances) [22] [40] [49] [50] [51]. The present results are technologically desirable for culinary formulations (e.g. jams, jellies and juices).

\subsection{AIS, Pectin Content and Pectinesterase Activity}

The AIS are mainly composed of pectin, starch and other plant cell materials [17] [52].

Table 1. Colorimetry of 118 cubiu peels evaluated at four ripening stages.

\begin{tabular}{ccccccc}
\hline \multirow{2}{*}{ Ripening Stages } & Fruit Sample & \multicolumn{5}{c}{ Color Features $^{\mathrm{a}}$} \\
\cline { 3 - 7 } & & $\mathrm{L}^{*}$ & $\mathrm{a}^{*}$ & $\mathrm{~b}^{*}$ & $\mathrm{C}^{*}$ & $\mathrm{~h}^{\circ}$ \\
\hline Green & 41 & $46.8 \pm 3.7 \mathrm{~b}$ & $-18.6 \pm 8.1 \mathrm{c}$ & $32.7 \pm 5.1 \mathrm{~b}$ & 37.6 & -1.1 \\
Turning & 26 & $60.9 \pm 7.1 \mathrm{a}$ & $-3.0 \pm 12.0 \mathrm{~b}$ & $57.3 \pm 11.3 \mathrm{a}$ & 57.4 & -1.5 \\
Ripe & 29 & $60.3 \pm 6.9 \mathrm{a}$ & $21.5 \pm 6.4 \mathrm{a}$ & $60.8 \pm 10.4 \mathrm{a}$ & 64.4 & 1.2 \\
Fully ripe & 22 & $34.6 \pm 3.5 \mathrm{c}$ & $24.4 \pm 3.5 \mathrm{a}$ & $18.0 \pm 6.0 \mathrm{c}$ & 30.3 & 0.6 \\
\hline
\end{tabular}

${ }^{\mathrm{a}}$ Means and standard deviation (SD) followed by the same letter did not significantly differ between variables at the level of $5 \%$ probability by the Tukey test. 
The results of AIS are illustrated in Figure 4. The highest content of AIS was found in green fruit peels. However, the decrease in AIS in other ripening stages was small, making of cubiu fruits rich sources in pectic substances at any stage of the fully developed fruits. The statistical analysis of dietary fiber content showed one modal value in the AIS. The Pearson correlation was also positive $(\mathrm{p}<0.05)$ between the AIS content and all the three studied tissue portions.

Figure 5 shows the pectin content in the peel and the placenta of cubiu fruits. The results clearly demonstrated a similar pattern of behavior in the tissue distribution of

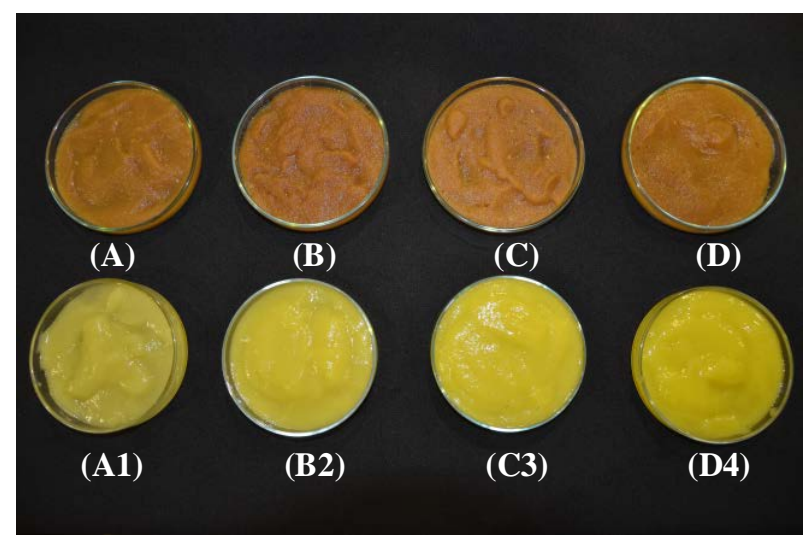

Figure 3. Beneficial effect of hot water blanching on the preservation of cubiu pulp colors. Note: Homogenized cubiu pulps at the (A) green, (B) turning, (C) ripe and (D) fully ripe stages without previous blanching and subsequent fast browning in less than 2 minutes (control process). Previously blanched and subsequently homogenized cubiu pulps at the (A1) green, (B2) turning, (C3) ripe and (D4) fully ripe stages with preservation of the natural colors of the pulp for 24 hours at ambient temperature (intervention process).

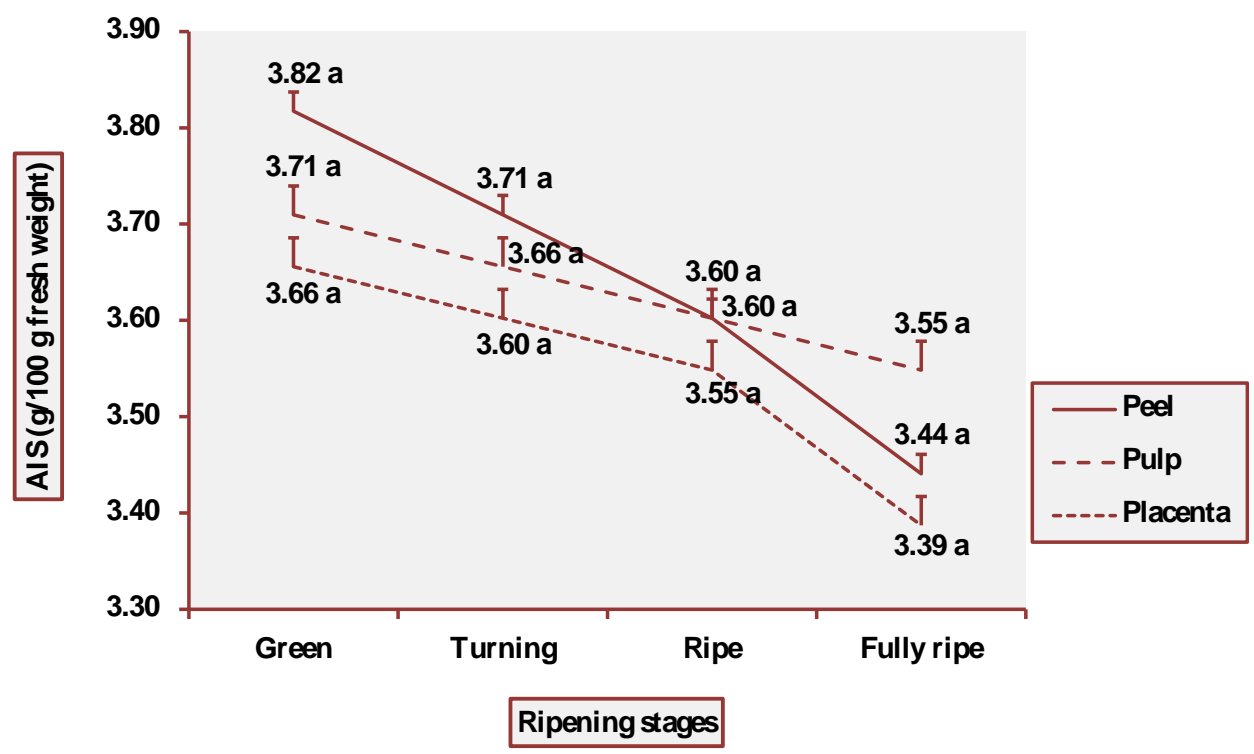

Figure 4. AIS behavior in three tissue portions of cubiu fruits at four ripening stages. Note: Means followed by the same letter did not significantly differ between variables at the level of $5 \%$ probability by the Tukey test. 
pectin content. Pectin, in fact, binds the cell wall layers together and assures 95\% - 97\% of the firmness of the fruits [53] [54]. On the other hand, during fruit ripening, pectin is degraded by pectinases (generic term for enzymes such as polygalacturonase (EC 3.2.1.15), pectin lyase (EC 4.2.2.10) and also pectin methylesterase or pectinesterase), partly explaining why the highest the pectinesterase activity, the lowest the pectin content, especially in the pulp of green cubiu fruits (Figure 6) [17]. The high pectinesterase activity in oat coleoptiles has already been associated with a possible role of pectinesterase

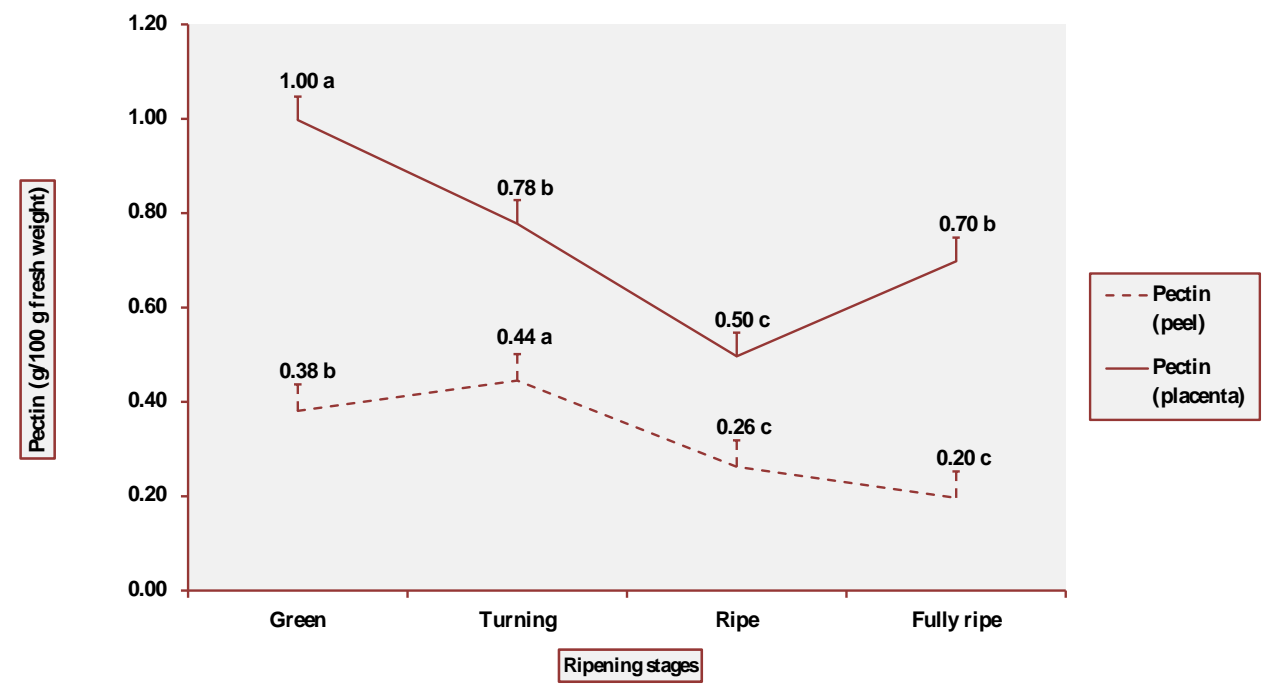

Figure 5. Pectin content in cubiu peel and placenta during ripening. Note: Means followed by the same letter did not significantly differ between variables at the level of $5 \%$ probability by the Tukey test.

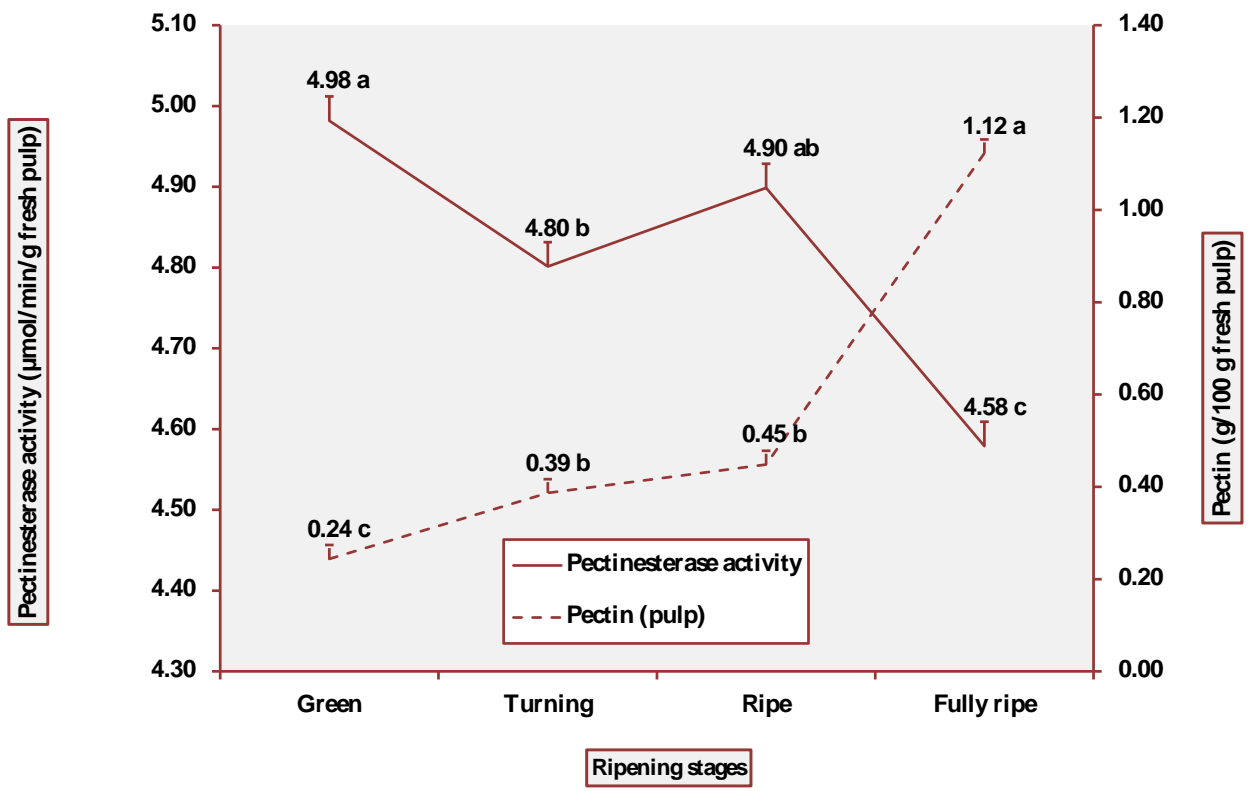

Figure 6. Characterization of pectinesterase activity and pectin in the pulp of ripening cubiu fruits. Note: Means followed by the same letter did not significantly differ between variables at the level of $5 \%$ probability by the Tukey test. 
and other biocatalysts (e.g. $\beta$-1,3-glucanase-EC 3.2.1.6) in initiating tissue expansion [55]. In the pulp of fully ripe cubiu fruits, the reverse reasoning is applicable to the pectinesterase activity (the lowest) and the pectin content (the highest). Nevertheless, it is important to note that cell wall modification is a multifactorial coordinated process (including non-enzymatic solubilization), and pectin depolymerization is a more specialized process than solubilization, suggesting that these two processes are not correlated [17].

Pectin fulfills the concept of a functional ingredient, i.e. a food component that provides health benefits beyond basic nutrition [56]. Pectin exerts various beneficial effects on human health [17]. For instance, pectin is believed to be beneficial in lowering blood cholesterol and plaque-forming low-density lipoprotein (LDL) levels by interrupting the enterohepatic circulation of bile salts, thereby increasing hepatic conversion of cholesterol into newly synthesized bile acids and decreasing serum LDL [57]. Cubiu fruits are a significant source of pectin, especially in green peels and fully ripe pulps, and should be considered in the dietary diversification of pectin.

\subsection{Cubiu Fruit Pigments (or Bioactive Compounds)}

The apparent colors of the fruits (and the subjacent pigments) are potent signals that attract diverse living beings for fruit consumption. The results of chlorophyll content in cubiu peels are illustrated in Figure 7. At the green stage, chlorophyll a was higher than chlorophyll $b$. The ratio of chlorophyll $a$ and chlorophyll $b$ is usually $3: 1$, and it attained 2.5:1 at the green peel [58]. However, chlorophyll a quickly decreased at the turning stage as it is degraded faster than chlorophyll $b$ [59]. The statistical analysis showed one modal value in chlorophyll $a$ at the turning and ripe stages and another modal value in chlorophyll $b$ at the ripe and fully ripe stages. The Pearson correlation was positive $(\mathrm{p}<$ 0.003 ) between chlorophyll $a$ and total.

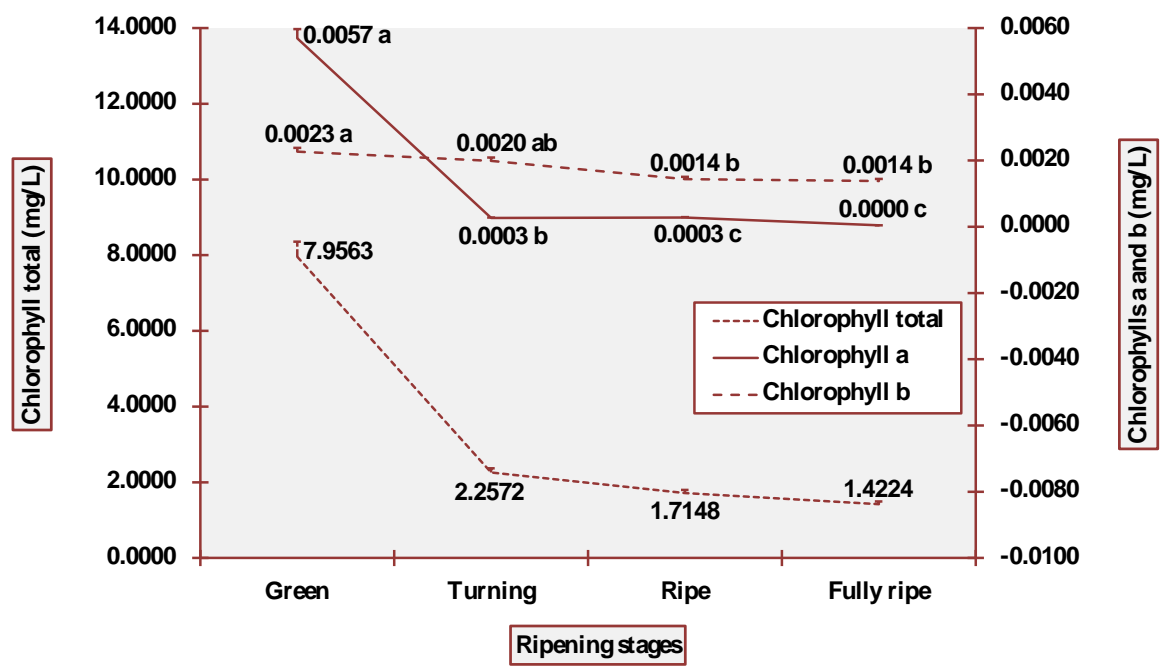

Figure 7. Chlorophyll levels in cubiu fruit peels during ripening. Note: Means followed by the same letter did not significantly differ between variables at the level of $5 \%$ probability by the $\mathrm{Tu}$ key test. 
The results of total flavonoid content are illustrated in Figure 8. The anthocyanins were entirely absent. From the green to the fully ripe peel, the total flavonoid content showed an ascendant curve. From the green to the fully ripe pulp, these pigments exhibited lower levels in a decent curve. In cubiu placenta, the total flavonoid content showed a sinusoidal curve with higher levels than those of the pulp, but still smaller than those of the peel.

The results of total carotenoid content are illustrated in Figure 9. From the green to the turning peel, the total carotenoid content increased progressively and significantly, then peaked in the ripe peel and slightly decreased in the fully ripe peel. There was an exponential growth in the total carotenoid content from the green to the fully ripe pulp. In placenta, there remained an increasing trend in the levels of these pigments, with higher values than those of the pulp. Hence, in the cultivars studied herein, the redpurple colors that appear in the fully ripe peels of cubiu fruits are due to carotenoids and not to anthocyanins.

Apart the importance of the biochemical characterization of cubiu fruit colors during ripening, there is growing evidence of the potential beneficial impact of pigments (or bioactive compounds) on human health. Hereafter, chlorophyll does not merely mean the generic name of green pigments that coat the fruit at this ripening stage, but also biomolecules capable of stimulating the immune system (with benefits against sinusitis, the accumulation of fluids and skin eruptions), combating anemia, detoxifying the body, preventing cancer, normalizing blood pressure, among other potential benefits [25].

Moreover, carotenoids that have provitamin A activity can be converted into retinol in vivo [60]. In humans, the conversion of $\beta$-carotene to vitamin A occurs predominantly

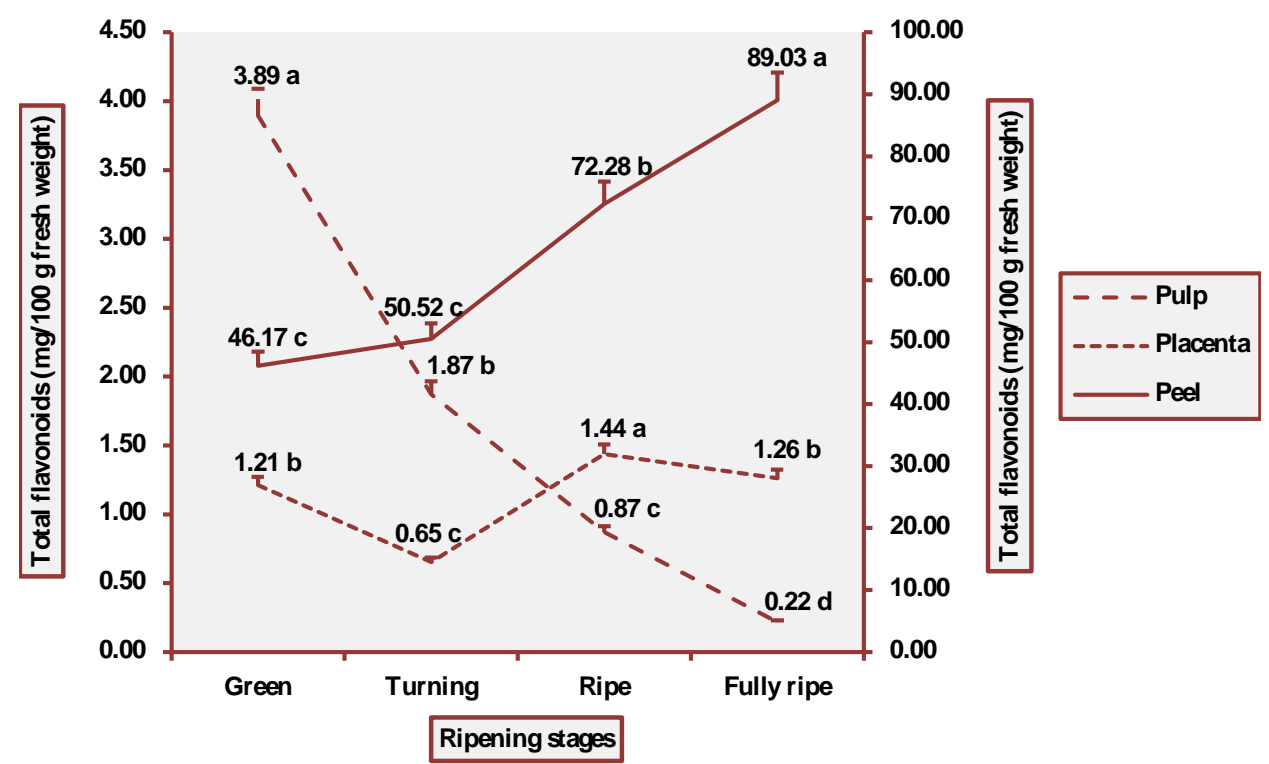

Figure 8. Total flavonoid levels in cubiu fruits during ripening. Note: Means followed by the same letter did not significantly differ between variables at the level of $5 \%$ probability by the Tukey test. 


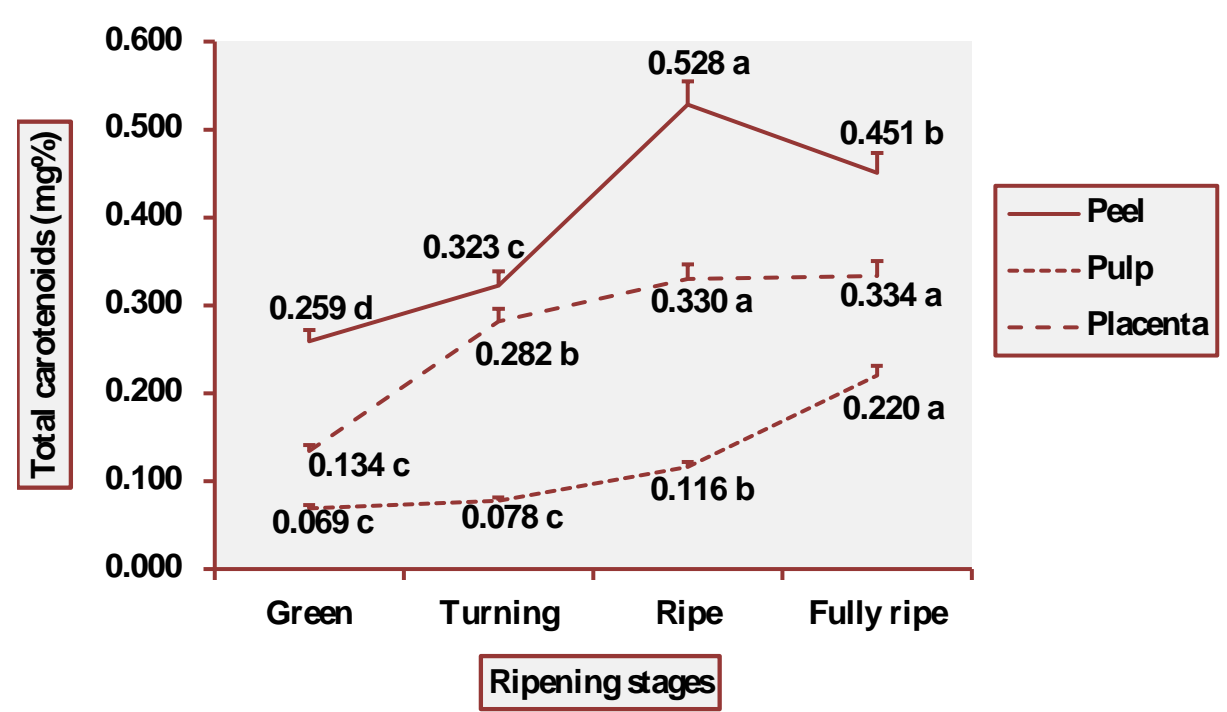

Figure 9. Total carotenoid levels in cubiu fruits during ripening. Note: Means followed by the same letter did not significantly differ between variables at the level of $5 \%$ probability by the $\mathrm{Tu}$ key test.

in the intestine and less in other tissues [61]. Vitamin A is then converted into the visual chromophore 11-cis retinal and into the retinoic acid hormone [62]. This hormone is important for visual function, acting as a ligand for nuclear receptors to modulate gene expression; its synthesis being finely controlled during the ocular globe formation between the fourth and the sixth week of human gestation [63]. In contrast to vitamin A and its potential toxicity (or hypervitaminosis A), carotenoids are not toxic even when ingested in large amounts (e.g. in anorexia nervosa and/or bulimia nervosa) due to their low intestinal absorption, but when the latter increases, the liposoluble pigments are deposited in the subcutaneous tissue, and the skin becomes yellow (hypercarotenosis or carotenodermia), a condition that usually resolves spontaneously [1] [24].

The term Dietary Reference Intakes (DRIs) refers to a set of four nutrient-based reference values, i.e. Recommended Dietary Allowance (RDA), Adequate Intake (AI), Tolerable Upper Intake Level (UL) and Estimated Average Requirement (EAR), which are fully developed in another work [64]. Despite the benefit on health attributed to carotenoids, no DRIs have been established for any of these compounds, but existing recommendations for increased consumption of carotenoid-rich fruits are supported [64]. Thus, fresh cubiu is a rich fruit in carotenoids that can contribute to achieve this daily goal in the human diet. Although it will be necessary to refine future studies in order to specify which carotenoids are predominant in cubiu fruits at the abovementioned ripening stages.

Similarly, despite the potential beneficial effects on health attributed to flavonoids (e.g. vasoprotective activity; cancer prevention; antioxidant, anti-inflammatory, antimicrobial and anti-allergic activities; synergistic action with ascorbic acid in protecting cutaneous tissue in culture), there are no established DRIs for such complex molecules either [63] [65]. 


\subsection{Freshness and Ripening Indices}

Cubiu moisture content is a major factor in determining the appearance of freshness of the fruit. The Figures 10-12 show the changes in moisture and dry matter of cubiu peel, pulp and placenta, respectively. The moisture of cubiu peel presented a linear,

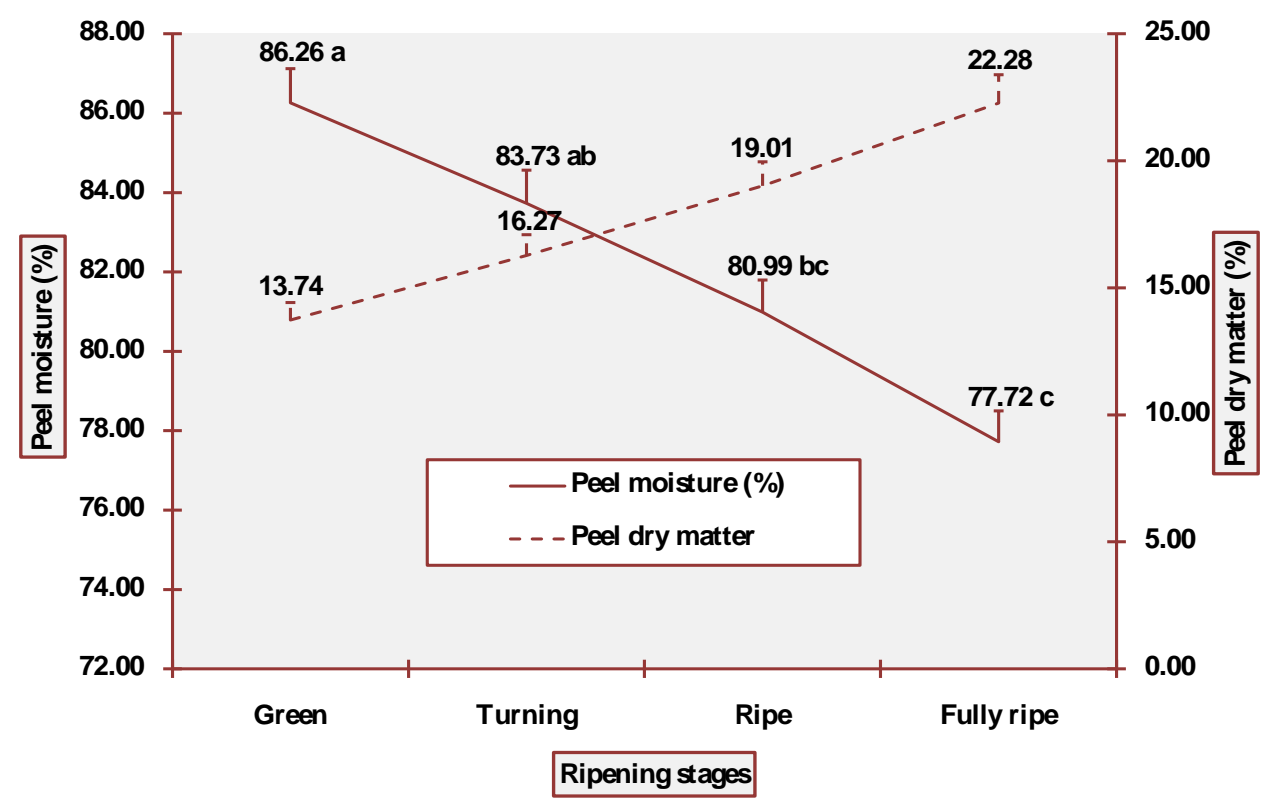

Figure 10. Moisture changes in cubiu fruit peel in the immediate postharvest period. Note: Means followed by the same letter did not significantly differ between variables at the level of 5\% probability by the Tukey test.

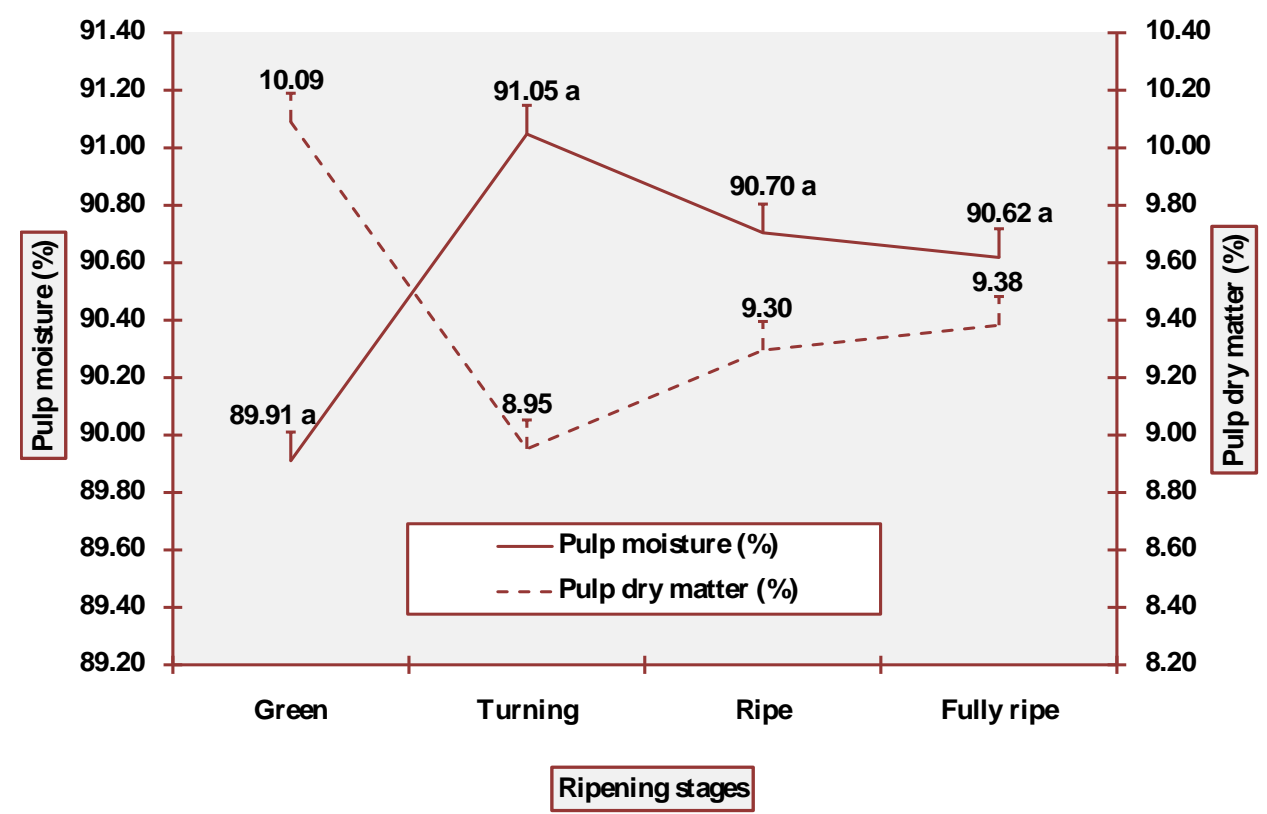

Figure 11. Moisture changes in cubiu fruit pulp in the immediate postharvest period. Note: Means followed by the same letter did not significantly differ between variables at the level of $5 \%$ probability by the Tukey test. 


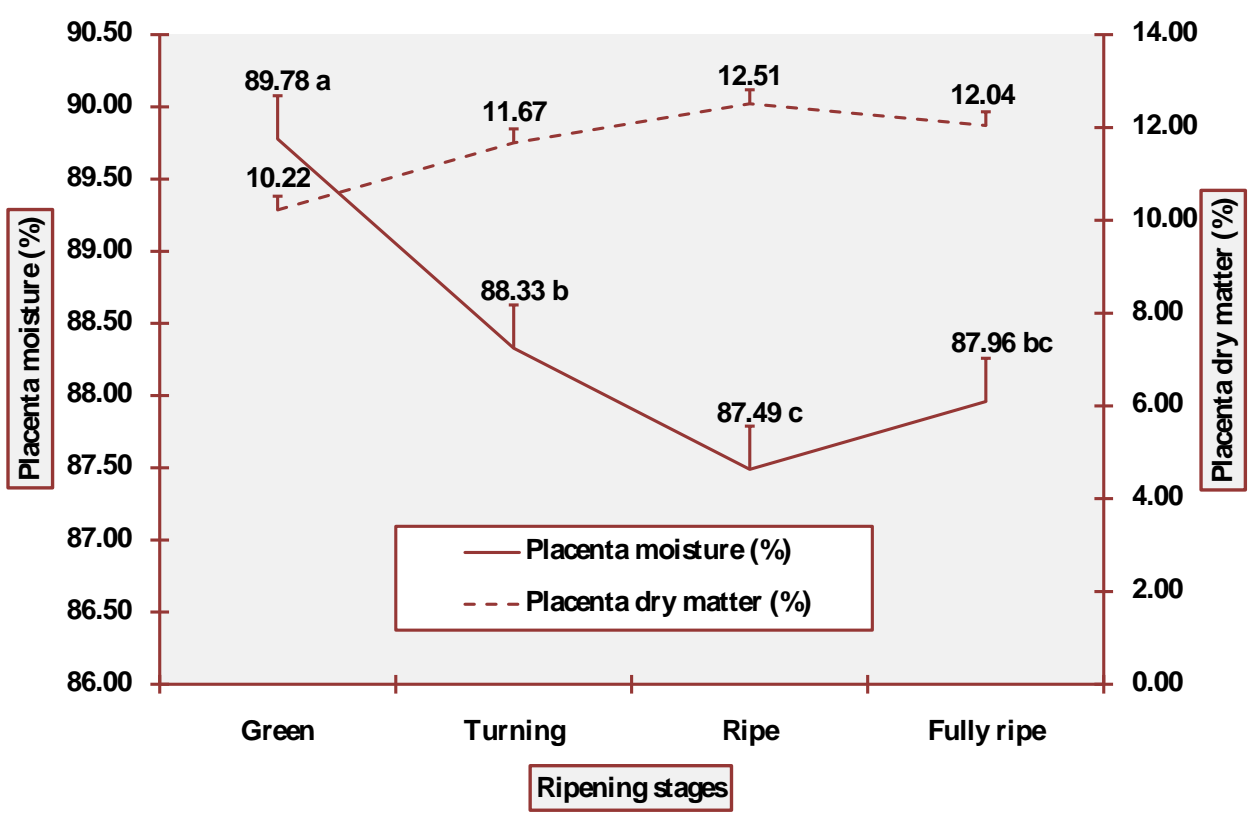

Figure 12. Moisture changes in cubiu fruit placenta in the immediate postharvest period. Note: Means followed by the same letter did not significantly differ between variables at the level of 5\% probability by the Tukey test.

descendent, regular and constant behavior. In cubiu pulp, there was a peak of moisture at the intersection of the green and turning stages, keeping up with approximate values at the ripe and fully ripe stages. In cubiu placenta, the moisture showed a small and steady decline from the green to the ripe fruit, with a slight increase in the fully ripe fruit.

Taking tomato fruit (Solanum sect. Lycopersicon (Mill.) Wettst.) as a model species, Solanaceae fleshy fruits (or berries) possess a peel composed of outer pericarp cells and a continuous layer of epidermal cells, covered with a thick waxy cuticle that thickens even more with the ripening of the fruits [66] [67]. Despite this complex apparatus of histochemical protection, the loss of fruit water may partly result of the respiration through the peel and the diffusion of water through the cuticle [68]. The loss of fruit water may also result of the fruit surface area exposed to the environment [69]. Thus, the pulp and the placenta are more protected from this vast exposure to the environment, saving the internal moisture of the fruit. However, moisture loss is an initial trigger for ripening; on the other hand, the greater retardation in moisture loss will increase the potential for extending storage life [1]. It is worth emphasizing the dietetic importance of the high percentage of moisture of cubiu fruits in all tissue portions and ripening stages investigated herein.

Figure 13 and Figure 14 show the behavior of TSS of cubiu pulp and placenta, respectively. There was a little change in TSS levels of cubiu pulp, with a small peak in the turning pulp and another peak more pronounced in the fully ripe pulp. From the green to the ripe placenta, TSS levels oscillated little, showing, however, an abrupt decline in the fully ripe placenta, probably associated with increased acidity and consequent decrease in $\mathrm{pH}$, as discussed below. 


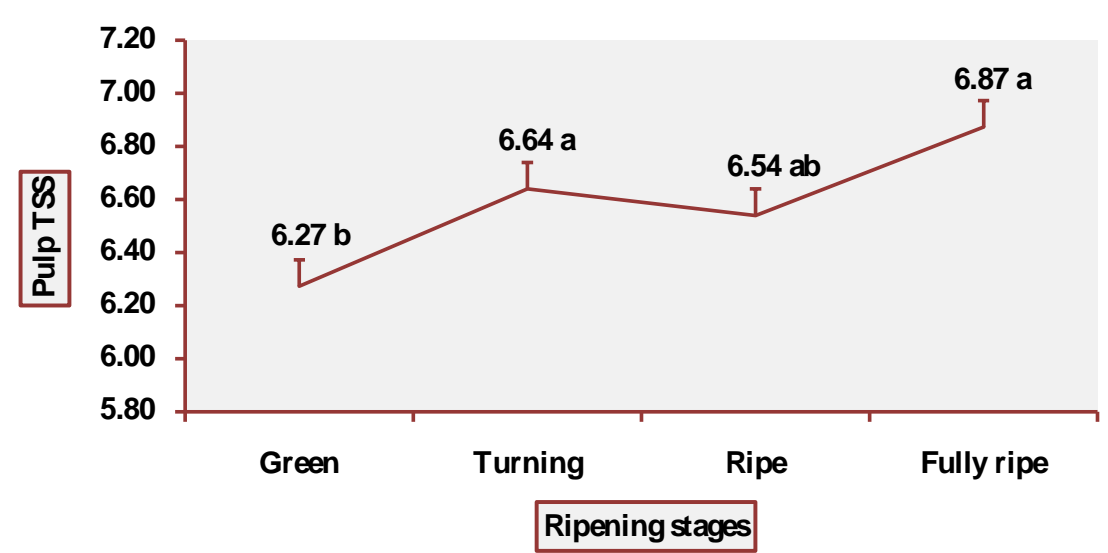

Figure 13. TSS behavior in cubiu fruit pulp in the immediate postharvest period. Note: Means followed by the same letter did not significantly differ between variables at the level of 5\% probability by the Tukey test.

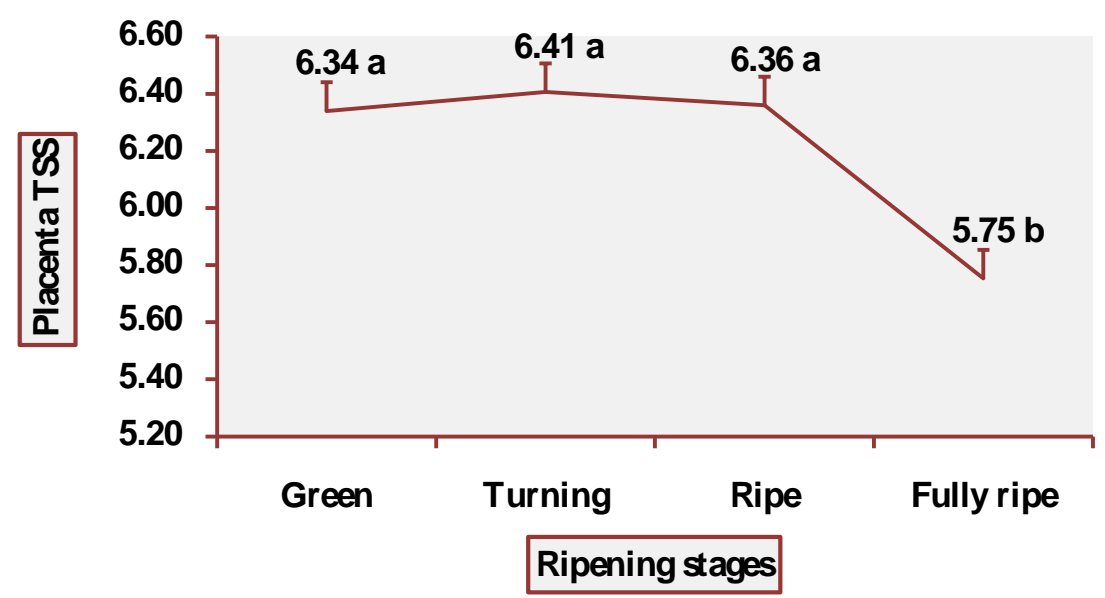

Figure 14. TSS behavior in cubiu fruit placenta in the immediate postharvest period. Note: Means followed by the same letter did not significantly differ between variables at the level of 5\% probability by the Tukey test.

Figure 15 and Figure 16 show the behavior of $\mathrm{pH}$ and TA of cubiu pulp and placenta, respectively.

Pulp pH and TA varied little at all stages, and it is statistically evident (Figure 15). Placenta $\mathrm{pH}$ was notably low and TA was remarkably high at the fully ripe stage. Once more, this profile contradicted the general axiom in which there is a considerable decrease in organic acid content during the ripening process [17]. In cubiu fruits, on the contrary, there is a considerable increase in the content of organic acids during the ripening process, especially in placenta. Organic acids have bactericidal activity and have been successfully used in bacterial disinfection (e.g. the Gram-negative Yersinia enterocolitica) of fresh vegetables [70]. Empirically, however, Amazonian natives use cubiu fruits instead of lemons not only to disinfect the fish, but also to decrease the pitiú (from the Tupi, meaning unpleasant smell, characteristic of raw fish) [71]. Additionally, cubiu fruits are devoid of the unpleasant (bitter) taste of lemons associated with the 


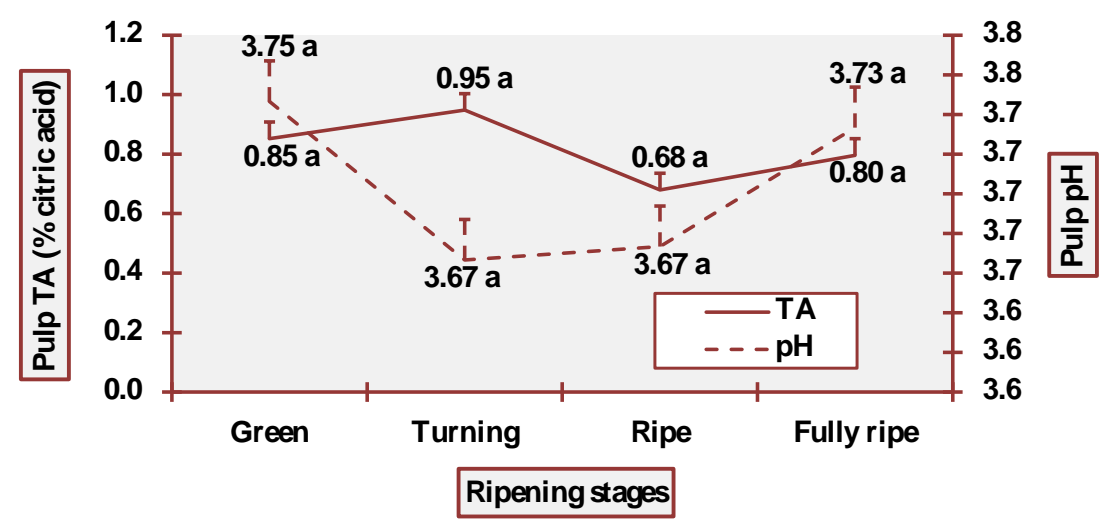

Figure 15. The $\mathrm{pH}$ and TA behavior of cubiu fruit pulp in the immediate postharvest period. Note: Means followed by the same letter did not significantly differ between variables at the level of $5 \%$ probability by the Tukey test.

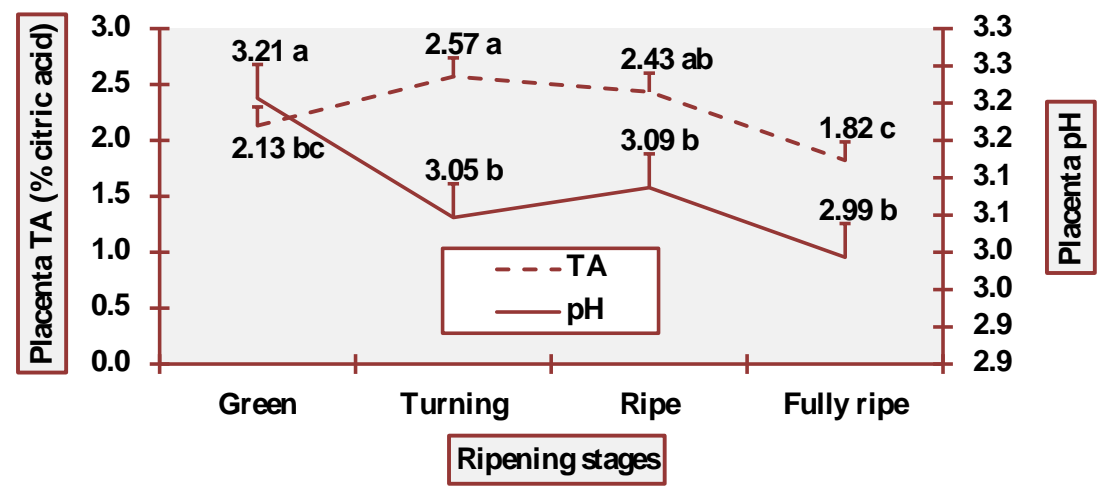

Figure 16. The $\mathrm{pH}$ and TA behavior of cubiu fruit placenta in the immediate postharvest period. Note: Means followed by the same letter did not significantly differ between variables at the level of $5 \%$ probability by the Tukey test.

citrus limonoids accumulated during ripening, especially nomilin (precursor of all limonoids) [72]. As a final point, organic acids along with sugars sharpen the flavor of cubiu fruits, characterizing it as very acidic with a small degree of sweetness [17].

Figure 17 and Figure 18 show the behavior of the TSS/TA ratio of cubiu pulp and placenta, respectively. These two figures clearly show the part that each component of the TSS/TA ratio played in the determination of the results. In cubiu pulp, there was a comprehensible predominance of TSS leading to an alignment towards the TSS whereas in cubiu placenta, there was, instead, an evident predominance of organic acids leading to an alignment towards the TA.

Figure 19 shows the ascorbic acid behavior in cubiu tissue portions by the spectrophotometric method. Table 2 displays the pertinent statistical analysis. Ascorbic acid is a versatile molecule, fulfilling the criteria of a bioactive compound (more recently) and (historically) those of a water-soluble vitamin (especially in the treatment of scurvy) [6] [24] [73] [74].

As summarized in Figure 20, ascorbic acid exerts other potential beneficial effects on living systems, some of which are not fully understood yet (e.g. anticancer effects) [24] 

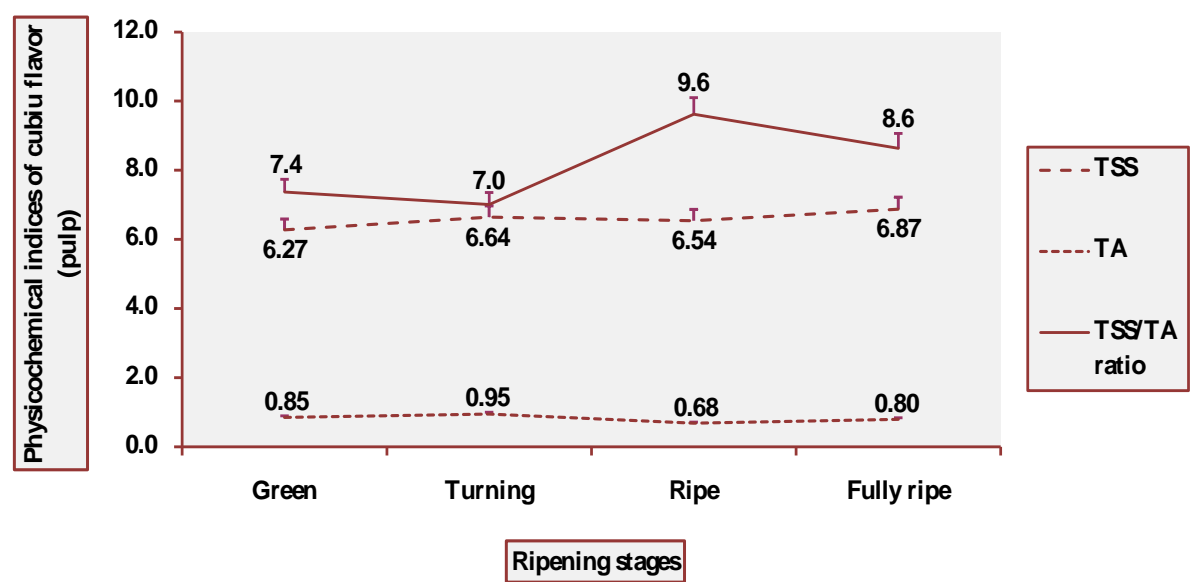

Figure 17. TSS/TA ratio behavior of cubiu pulp during ripening. Note: Means followed by the same letter did not significantly differ between variables at the level of $5 \%$ probability by the $\mathrm{Tu}-$ key test.
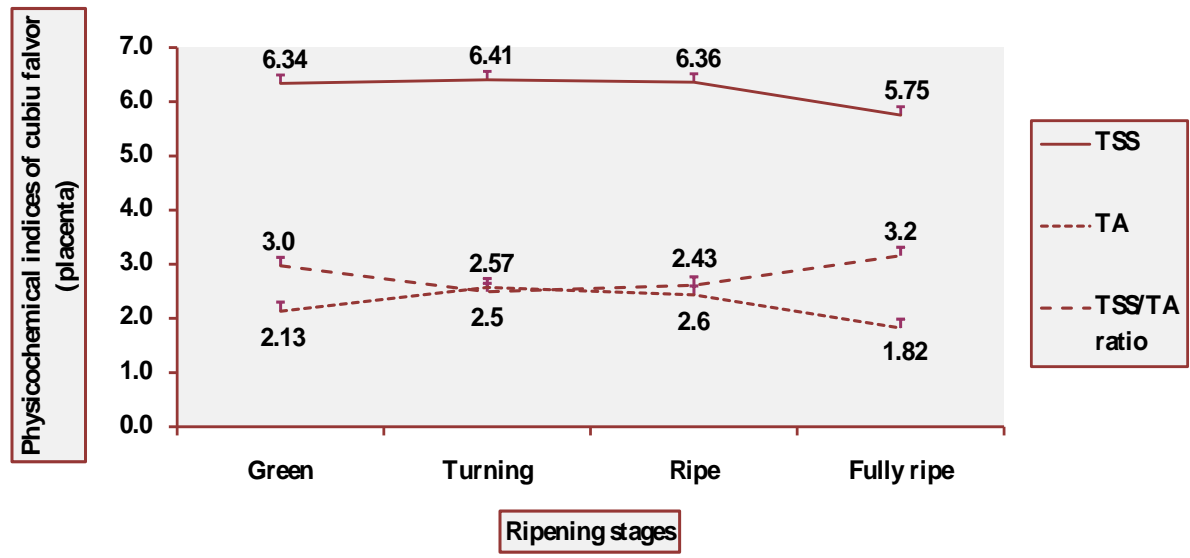

Figure 18. TSS/TA ratio behavior of cubiu placenta during ripening. Note: Means followed by the same letter did not significantly differ between variables at the level of $5 \%$ probability by the Tukey test.

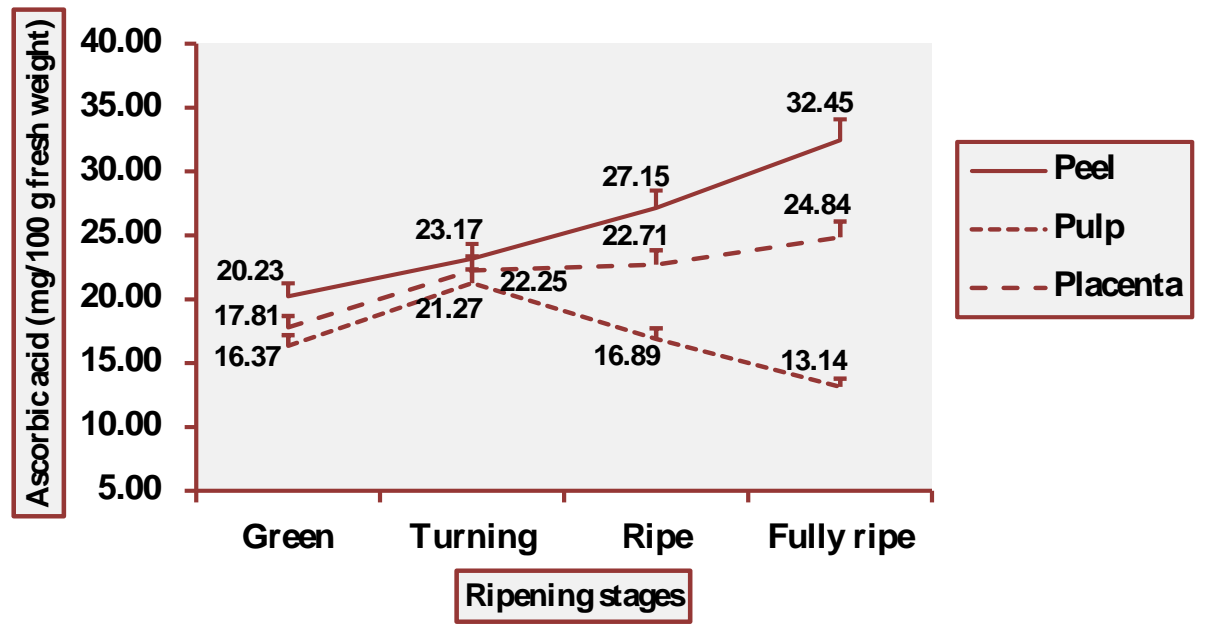

Figure 19. Ascorbic acid behavior in cubiu fruit tissues during ripening. 
Table 2. Statistical analysis of cubiu ascorbic acid content according to different tissue portions and ripening stages.

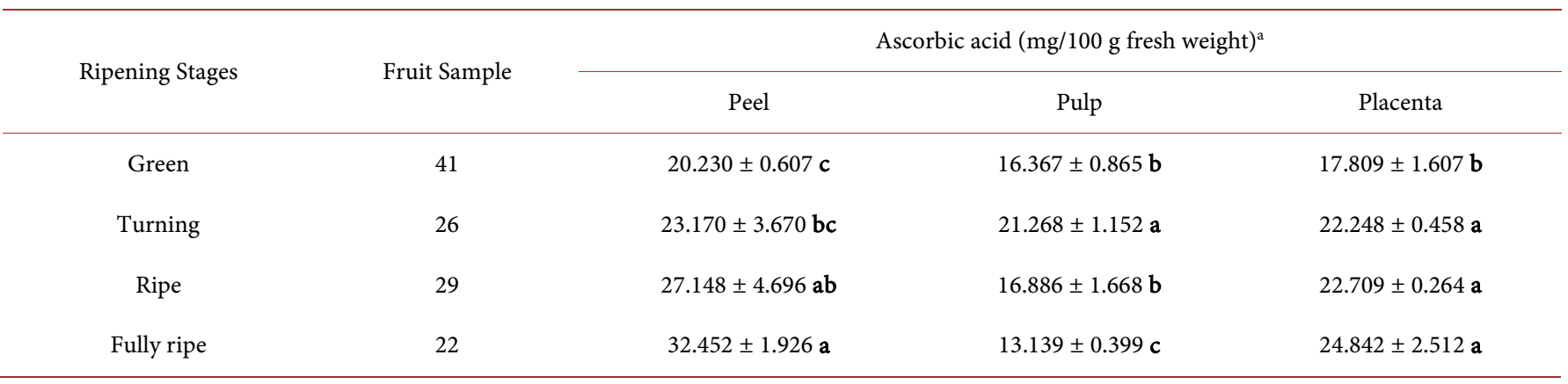

${ }^{a}$ Means and SD followed by the same letter did not differ significantly between variables at the level of $5 \%$ probability by the Tukey test.

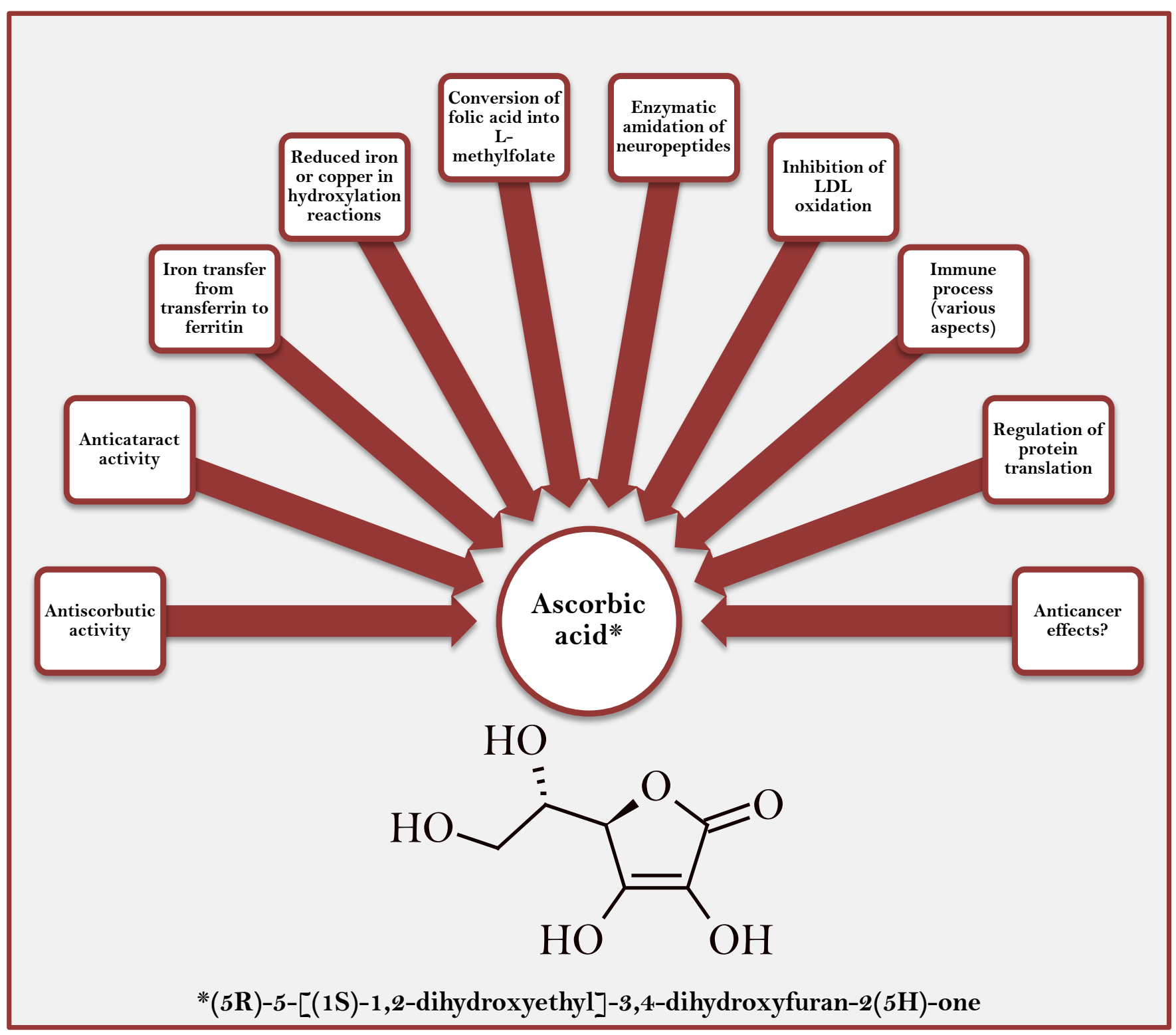

Figure 20. Other potential beneficial effects of ascorbic acid on living systems. Adapted from [24] [75] [76] [77] [78] [79]. 
[75] [76] [77] [78] [79]. Ascorbic acid is uniformly distributed in fruit tissues whereas phenolic compounds (e.g. flavonoids) are preferably located in the peel and to a lesser extent in the pulp [80]. This observation is in accordance with the present results. The DRI (RDA) for adults is $60 \mathrm{mg}$ of ascorbic acid per day [24] [81]. Cubiu is a rich fruit in ascorbic acid-particularly the peel and the placenta at the fully ripe stage-and should be included in the human diet as a palatable source of this essential micronutrient. Besides, its remarkable content in iron makes it recommendable for iron-deficiency anemia [17]. Unfortunately, there are no other studies comparing the ascorbic acid content in cubiu tissues at different ripening stages. There is also a lack of studies comparing the ascorbic acid content in different tissue portions of other Solanaceae fruits at diverse ripening stages. The pertinent studies available, for the most part, make the comparison difficult because they take into account only the content of ascorbic acid in the pulp of ripe fruits and use a different analytical method (e.g. titrimetric instead of spectrophotometric). To finish, regardless of the high content of ascorbic acid, TA and pectin in cubiu fruits, the expression "citric fruit" is reserved for the fruit species of the genus Citrus L. of the Rutaceae family.

\section{Conclusion}

Edible fruits, such as cubiu, are the corollary of selection, domestication and long breeding practices for desirable traits. In the last 20 years, laboratory research has partly revealed the biochemical composition of cubiu fruits. This current work was pioneering in presenting the biochemical composition of cubiu fruits according to different tissue portions and ripening stages. With such a design, it was possible to learn more about cubiu placenta. Actually, placenta is a poorly investigated fruit tissue portion (in general) and in cubiu fruit (in particular). The present study sought not only to clarify the ripening process of cubiu fruits, but also to get the most out of their technological and dietetic potentialities. The study of the effects of blanching on cubiu pulp coloration, besides its relevance as background information, may be supplemented with quantitative information (e.g. kinetics of peroxidase inactivation) in future work. Furthermore, the richness of cubiu placenta in ascorbic acid should arouse the interest of food scientists and food technologists for designing more related studies. The approach of bioactive compounds (e.g. chlorophylls, flavonoids, carotenoids, ascorbic acid) is complex and therefore, multidisciplinary. DRIs are still non-existent for most of the bioactive compounds and (most certainly) are not keeping pace with the rapid emergence of new food sources. It points out to the continuing need for multidisciplinary cooperation in the solution of such important diet-related problems.

\section{Acknowledgements}

The authors are grateful to the financial support provided by Fundação de Amparo à Pesquisa do Estado do Amazonas (FAPEAM). The authors are also grateful to Jackson Dinajar Saraiva Feijó for his technical assistance in the preparation of this manuscript. 


\section{References}

[1] Andrade Jr., M.C. and Andrade, J.S. (2012) Physicochemical Changes in Cubiu Fruits (Solanum sessiliflorum Dunal) at Different Ripening Stages. Food Science and Technology, 32, 250-254. http://dx.doi.org/10.1590/S0101-20612012005000049

[2] Whalen, M., Costish, D. and Heiser, C. (1981) Taxonomy of Solanum Section Lasiocarpa. Gentes Herbarum, 12, 41-129.

[3] Andrade, J.S., Freitas, F.M.N.O., Caceres, L.G. and Figueiredo, J.N.R. (2013) Technologies for Drying Cubiu (Solanum sessiliflorum Dunal) [Tecnologias para Secagem do Cubiu (Solanum sessiliflorum Dunal)]. In: Noda, H., Souza, L.A.G. and Silva Filho, D.F., Eds., Family Agriculture in Amazonas: Conservation of Environmental Resources [Agricultura Familiar No Amazonas: Conservação dos Recursos Ambientais], Wega, Manaus, 57-70.

[4] Silva, D.F.P., Rocha, R.H.C. and Salomão, L.C.C. (2011) Postharvest Quality of Cocona (Solanum sessiliflorum Dunal) Stored under Ambient Condition. Revista Ceres, 58, 476480. http://dx.doi.org/10.1590/s0034-737x2011000400011

[5] Stefanello, S., Schuelter, A.R., Scapim, C.A., Finger, F.L., Pereira, G.M., Bonato, C.M., Rocha, A.C.S. and Silva, J.M. (2010) Postharvest Ripening of Ethephon-Treated Cubiu (Solanum sessiliflorum Dunal) Fruits. Acta Amazonica, 40, 425-434. http://dx.doi.org/10.1590/S0044-59672010000300003

[6] Andrade Jr., M.C. and Andrade, J.S. (2014) Amazonian Fruits: An Overview of Nutrients, Calories and Use in Metabolic Disorders. Food and Nutrition Sciences, 5, 1692-1703. http://www.scirp.org/journal/PaperInformation.aspx?PaperID=49580\&\#abstract http://dx.doi.org/10.4236/fns.2014.517182

[7] Berry, T. and Bewley, J.D. (1992) A Role for the Surrounding Fruit Tissues in Preventing the Germination of Tomato (Lycopersicon esculentum) Seeds. Plant Physiology, 100, 951957. http://dx.doi.org/10.1104/pp.100.2.951

[8] Yuyama, L.K.O., Pantoja, L., Maeda, R.N., Aguiar, J.P.L. and Silva S.B.D. (2008) Development and Acceptability of a Low Calorie Cubiu (Solanum sessiliflorum Dunal) Jam. Food Science and Technology, 28, 929-934. http://dx.doi.org/10.1590/S0101-20612008000400026

[9] Alexander, L. and Grierson, D. (2002) Ethylene Biosynthesis and Action in Tomato: A Model for Climacteric Fruit Ripening. Journal of Experimental Botany, 53, 2039-2055. http://dx.doi.org/10.1093/jxb/erf072

[10] Infante, R., Rubio, P., Contador, L., Noferini, M. and Costa, F. (2011) Ripe Nectarines Segregated through Sensory Quality Evaluation and Electronic Nose Assessment. Fruits, 66, 109-119. http://dx.doi.org/10.1051/fruits/2011020

[11] Infante, R., Rubio, P., Contador, L., Noferini, M. and Costa, F. (2011) Determination of Harvest Maturity of D'Agen Plums Using the Chlorophyll Absorbance Index. Ciencia e Investigación Agraria, 38, 199-203. http://dx.doi.org/10.4067/S0718-16202011000200004

[12] Wills, R.B.H., Lee, T.H., Graham, D., McGlasson, W.B. and Hall, E.G. (1982) Postharvest: An Introduction to the Physiology and Handling of Fruit and Vegetables. New South Wales University Press Limited, Kensington.

[13] Wang, Y. and Chen, R. (2014) Regulation of Compound Leaf Development. Plants, 3, 1-17. http://dx.doi.org/10.3390/plants3010001

[14] Féret, J.-B., François, C., Gitelson, A., Asner, G.P., Barry, K.M., Panigada, C., Richardson, A.D. and Jacquemoud, S. (2011) Optimizing Spectral Indices and Chemometric Analysis of Leaf Chemical Properties Using Radiative Transfer Modeling. Remote Sensing of Environment, 115, 2742-2750. http://dx.doi.org/10.1016/j.rse.2011.06.016 
[15] Ashan, G. and Pfanz, H. (2003) Non-Foliar Photosynthesis-A Strategy of Additional Carbon Acquisition. Flora-Morphology, Distribution, Functional Ecology of Plants, 198, 8197. http://dx.doi.org/10.1078/0367-2530-00080

[16] Martinelli, F., Basile, B., Morelli, G., D’Andria, R. and Tonutti, P. (2012) Effects of Irrigation on Fruit Ripening Behavior and Metabolic Changes in Olive. Scientia Horticulturae, 144, 201-207. http://dx.doi.org/10.1016/j.scienta.2012.07.012

[17] Andrade Jr., M.C. and Andrade, J.S. (2015) Changes in Pectinases, Dietary Fibers, and Physicochemical Indices Related to the Flavor of Cubiu Fruits During Ripening. Acta Scientiarum-Agronomy, 37, 171-179. http://dx.doi.org/10.4025/actasciagron.v37i2.19683

[18] Lichanporn, I., Srilaong, V., Wongs-Aree, C. and Kanlayanarat, S. (2009) Postharvest Physiology and Browning of Longkong (Aglaia dookkoo Griff.) Fruit under Ambient Conditions. Postharvest Biology and Technology, 52, 294-299.

http://dx.doi.org/10.1016/j.postharvbio.2009.01.003

[19] Landi, M., Fambrini, M., Basile, A., Salvini, M., Guidi, L. and Pugliesi, C. (2015) Overexpression of L-Galactono-1,4-Lactone Dehydrogenase (L-GalLDH) Gene Correlates with Increased Ascorbate Concentration and Reduced Browning in Leaves of Lactuca sativa L. after Cutting. Plant Cell, Tissue and Organ Culture, 123, 109-120.

http://dx.doi.org/10.1007/s11240-015-0819-y

[20] Villamiel, M., Del Castillo, M.D. and Corzo, N. (2006) Browning Reactions. In: Hui, Y.H., Ed., Food Biochemistry and Food Processing, Blackwell Publishing, Ames, 71-100. http://dx.doi.org/10.1002/9780470277577.ch4

[21] Joy, O. and Eze, S.O.O. (2015) Partial Purification and Characterizaton of Peroxidase Extracted from Gongronema latifolium. American-Eurasian Journal of Scientific Research, 10, 221-227.

[22] Jittanit, W., Wiriyaputtipong, S., Charoenpornworanam, H. and Songsermpong, S. (2011) Effects of Varieties, Heat Pretreatment and UHT Conditions on the Sugarcane Juice Quality. Chiang Mai Journal of Science, 38, 116-125.

[23] Wiegand, E.H., Madsen, H.S. and Price, F.E. (1943) Commercial Dehydration of Fruits and Vegetables. Oregon Agricultural Experiment Station Bulletin, 417, 3-39.

[24] Spallholz, J.E., Boylan, L.M. and Driskell, J.A. (1999) Nutrition: Chemistry and Biology. CRC Press, Boca Raton.

[25] İnanç, A.L. (2011) Chlorophyll: Structural Properties, Health Benefits and Its Occurrence in Virgin Olive Oils. Akademik Gida, 9, 26-32.

[26] Song, N., Yang, H., Pang, W., Qie, Z., Lu, H., Tan, L., Li, H., Sun, S., Lian, F., Qin, C. and Jiang, Y. (2014) Mulberry Extracts Alleviate a $\beta 25$ - $\beta 35$-Induced Injury and Change the Gene Expression Profile in PC12 Cells. Evidence-Based Complementary and Alternative Medicine, 2014, Article ID: 150617. http://dx.doi.org/10.1155/2014/150617

[27] Souza, M.P., Vaz, A.F.M., Cerqueira, M.A., Texeira, J.A., Vicente, A.A. and Carneiro-da-Cunha, M.G. (2015) Effect of an Edible Nanomultilayer Coating by Electrostatic SelfAssembly on the Shelf Life of Fresh-Cut Mangoes. Food Bioprocess Technology, 8, 647-654. http://dx.doi.org/10.1007/s11947-014-1436-1

[28] Magwazaa, L.S. and Oparab, U.L. (2015) Analytical Methods for Determination of Sugars and Sweetness of Horticultural Products-A Review. Scientia Horticulturae, 184, 179-192. http://dx.doi.org/10.1016/j.scienta.2015.01.001

[29] Armesto, J., Carballo, J. and Martínez, S. (2015) Physicochemical and Phytochemical Properties of Two Phenotypes of Galega Kale (Brassica oleracea L. var. Acephala cv. Galega). Journal of Food Biochemistry, 39, 439-448. http://dx.doi.org/10.1111/jfbc.12151 
[30] Keng, S.E., Al-Karkhi, A.F.M., Talib, M.K.M., Easa, A.M. and Hoong, C.L. (2015) An Investigation of Potential Fraud in Commercial Orange Juice Products in Malaysian Market by Cluster Analysis and Principal Component Analysis. Malaysian Journal of Analytical Sciences, 19, 377-387.

[31] Dorofejeva, K., Rakcejeva, T., Galoburda, R., Dukalska, L. and Kviesis, J. (2011) Vitamin C Content in Latvian Cranberries Dried in Convective and Microwave Vacuum Driers. Procedia Food Science, 1, 433-440. http://dx.doi.org/10.1016/j.profoo.2011.09.067

[32] Álvarez, R., Carvalho, C.P., Sierra, J., Lara, O., Cardona, D. and Londono-Londono, J. (2012) Citrus Juice Extraction Systems: Effect on Chemical Composition and Antioxidant Activity of Clementine Juice. Journal of Agricultural and Food Chemistry, 60, 774-781. http://dx.doi.org/10.1021/jf203353h

[33] Voragen, A.G.J., Coenen, G.-J., Verhoef, R.P. and Schols, H.A. (2009) Pectin, a Versatile Polysaccharide Present in Plant Cell Walls. Structural Chemistry, 20, 263-275. http://dx.doi.org/10.1007/s11224-009-9442-z

[34] Liu, Y., Che, F., Wang, L., Meng, R., Zhang, X. and Zhao, Z. (2013) Fruit Coloration and Anthocyanin Biosynthesis after Bag Removal in Non-Red and Red Apples (Malus $\times$ domestica Borkh.). Molecules, 18, 1549-1563. http://dx.doi.org/10.3390/molecules18021549

[35] McGuire, R.G. (1992) Reporting of Objective Color Measurements. HortScience, 27, 12541255.

[36] Gözlekçi, Ş., Saraçoğlu, O., Onursal, E. and Özgen, M. (2011) Total Phenolic Distribution of Juice, Peel, and Seed Extracts of Four Pomegranate Cultivars. Pharmacognosy Magazine, 7, 161-164. http://dx.doi.org/10.4103/0973-1296.80681

[37] HUNTERLAB (1996) CIE L*a*b* Color Scale. Application Note, 8, 1-4.

[38] Yap, A.U.J., Tan, K.B.C. and Sameer, B. (1997) Comparison of Aesthetic Properties of Tooth-Colored Restorative Materials. Operative Dentistry, 22, 167-172.

[39] Oke, M. and Paliyath, G. (2006) Biochemistry of Vegetable Processing. In: Hui, Y.H., Ed., Food Biochemistry and Food Processing, Blackwell Publishing, Ames, 537-554. http://dx.doi.org/10.1002/9780470277577.ch23

[40] Potter, N.N. and Hotchkiss, J.H. (1998) Food Science. An Aspen Publication, Gaithersburg.

[41] Jen, J.J. and Robinson, M.L. (1984) Pectolytic Enzymes in Sweet Bell Peppers (Capsicum annum L.). Journal of Food Science, 49, 1085-1087. http://dx.doi.org/10.1111/j.1365-2621.1984.tb10398.x

[42] Andrade, J.S. (1991) Maturation Curves and Nutritional Characteristics of Camu-Camu Myrciaria duabia (HBK) Mark Vaughn Grown in Upland in the Brazilian Central Amazonia [Curvas de Maturação e Características Nutricionais do Camu-Camu Myrciaria duabia (HBK). Mc Vaugh Cultivado em Terra Firme na Amazônia Central Brasileira]. Thesis, Universidade Estadual de Campinas (UNICAMP), Campinas.

[43] Xie, X., Gu, W., Gao, S., Lu, S., Li, J., Pan, G., Wang, G. and Shen, S. (2013) Alternative Electron Transports Participate in the Maintenance of Violaxanthin De-Epoxidase Activity of Ulva sp. under Low Irradiance. PLoS ONE, 8, e78211. http://dx.doi.org/10.1371/journal.pone.0078211

[44] Arnon, D.I. (1949) Copper Enzymes in Isolated Chloroplasts. Polyphenoloxidase in Beta vulagaris. Plant Physiology, 24, 1-15. http://dx.doi.org/10.1104/pp.24.1.1

[45] Passos, L.P. (1996) Analytical and Laboratory Methods in Plant Physiology, Métodos Analíticos e Laboratoriais em Fisiologia Vegetal. EMBRAPA-CNPGL, Coronel Pacheco.

[46] Trindade Jr., G., Argolo, R.C., Da Silva, M.V., Teixeira, H.L. and Rego Júnior, N.O. (2010) 
Irrigation Effect on the Condensed Tannin Levels in Tanzania Grass [Efeito da Irrigação sobre os Teores de Taninos Condensados em Capim Tanzânia]. Publicações em Medicina Veterinária e Zootecnia, 4, 1-12.

[47] Lees, D.H. and Francis, F.J. (1972) Standardization of Pigment Analyses in Cranberries. HortScience, 7, 83-84.

[48] De Albuquerque, J.R.T., Dos Santos Formiga, A., Da Rocha, T.C., Da Costa, F.B. and De Oliveira Gondim, A.R. (2015) Beet Postharvest Quality Subjected to Fertilization with Fermented Biofertilizers [Qualidade Pós-colheita de Beterraba Submetida à Adubação com Biofertilizante Fermentado]. Revista Verde de Agroecologia e Desenvolvimento Sustentável, 10, 41-46. http://dx.doi.org/10.18378/rvads.v10i3.3652

[49] Xiao, H.-W., Bai, J.-W., Sun, D.-W. and Gao, Z.-J. (2014) The Application of Superheated Steam Impingement Blanching (SSIB) in Agricultural Products Processing-A Review. Journal of Food Engineering, 132, 39-47. http://dx.doi.org/10.1016/j.jfoodeng.2014.01.032

[50] Elfnesh, F., Tekalign, T. and Solomon, W. (2011) Processing Quality of Improved Potato (Solanum tuberosum L.) Cultivars as Influenced by Growing Environment and Blanching. African Journal of Food Science, 5, 324-332.

[51] Badwaik, L.S., Gautam, G. and Deka S.C. (2015) Influence of Blanching on Antioxidant, Nutritional and Physical Properties of Bamboo Shoot. Journal of Agricultural Sciences, 10, 140-150. http://dx.doi.org/10.4038/jas.v10i3.8067

[52] Chaimanee, P. and Suntornwat, O. (1994) Changes in Carbohydrate Content During Fruit Ripening-A New Approach of Teaching of Carbohydrate Chemistry in Biochemistry Course. Biochemical Education, 22, 101-102. http://dx.doi.org/10.1016/0307-4412(94)90098-1

[53] Rosales-Reynoso, O.L., Agama-Acevedo, E., Aguirre-Cruz, A., Bello-Perez, L.A., Dufour, D. and Gibert, O. (2014) Physicochemical Evaluation of Cooking and Dessert Bananas (Musa sp.) Varieties. Agrociencia, 48, 387-401.

[54] Fuentesa, C.A., Tingb, K.W., Dupont-Gillainc, C., Steensmad, M., Talmad, A.G., Zuijderduind, R. and Van Vuurea, A.W. (2016) Effect of Humidity during Manufacturing on the Interfacial Strength of Non-Pre-Dried Flax Fibre/Unsaturated Polyester Composites. Composites Part A: Applied Science and Manufacturing, 84, 209-215. http://dx.doi.org/10.1016/j.compositesa.2016.01.023

[55] Masuda, Y. (1968) Role of Cell-Wall-Degrading Enzymes in Cell-Wall Loosening in Oat Coleoptiles. Planta, 83, 171-184. http://dx.doi.org/10.1007/BF00385022

[56] Andrade Jr., M.C. and Andrade, J.S. (2015) Fermented Foods in General and Ethnic Fermented Foods in Particular. LAP Lambert Academic Publishing, Saarbrüken.

[57] Eswaran, S., Muir, J. and Chey, W.D. (2013) Fiber and Functional Gastrointestinal Disorders. The American Journal of Gastroenterology, 108, 718-727. http://dx.doi.org/10.1038/ajg.2013.63

[58] Bresinsky, A., Körner, C., Kadereit, J.W., Neuhaus, G. and Sonnewald, U. (2012) Strasburger's Textbook of Botany [Tratado de Botânica de Strasburger]. ARTMED, Porto Alegre.

[59] Bompadre, M.J., Fernández Bidondo, L., Silvani, V.A., Colombo, R.P., Pérgola, M., Pardo, A.G. and Godeas, A.M. (2015) Combined Effects of Arbuscular Mycorrhizal Fungi and Exogenous Cytokinins on Pomegranate (Punica granatum) under Two Contrasting Water Availability Conditions. Symbiosis, 65, 55-63. http://dx.doi.org/10.1007/s13199-015-0318-2

[60] Yuan, J.-M., Gao, Y.-T., Ong, C.-N., Ross, R.K. and Yu, M.C. (2006) Prediagnostic Level of Serum Retinol in Relation to Reduced Risk of Hepatocellular Carcinoma. Journal of the National Cancer Institute, 98, 482-490. http://dx.doi.org/10.1093/jnci/djj104 
[61] Tang, G. (2001) Bioconversion of Dietary Provitamin A Carotenoids to Vitamin A in Humans. American Journal of Clinical Nutrition, 91, 1468S-1473S.

http://dx.doi.org/10.3945/ajcn.2010.28674G

[62] Harrison, E.H. (2012) Mechanisms Involved in the Intestinal Absorption of Dietary Vitamin A and Provitamin A Carotenoids. Biochimica et Biophysica Acta, 1821, 70-77. http://dx.doi.org/10.1016/j.bbalip.2011.06.002

[63] Plaisancié, J., Brémond-Gignac, D., Demeer, B., Gaston, V., Verloes, A., Fares-Taie, L., Gerber, S., Rozet, J.-M., Calvas, P. and Chassaing, N. (2016) Incomplete Penetrance of Biallelic ALDH1A3 Mutations. European Journal of Medical Genetics, 59, 215-218. http://dx.doi.org/10.1016/j.ejmg.2016.02.004

[64] National Academy of Sciences (2000) Dietary Reference Intakes for Vitamin C, Vitamin E, Selenium, and Carotenoids. National Academy Press, Washington DC.

[65] Schaneberg, B. (2011) AOAC Proposal on Flavonoid Measurement and Terminology. AOAC International, Rockville.

[66] Mandel, T., Rogachev, I., Venger, I., Mintz-Oron, S., Aharoni, A. and Adato A. (2007) The Ins and Outs of Tomato Fruit Peel Metabolome. Acta Horticulturae, 814, 465-474.

[67] Lara, I., Belge, B. and Goulao, L.F. (2015) A Focus on the Biosynthesis and Composition of Cuticle in Fruits. Journal of Agricultural and Food Chemistry, 63, 4005-4019. http://dx.doi.org/10.1021/acs.jafc.5b00013

[68] Lownds, N.K., Banaras, M. and Bosland, P.W. (1994) Postharvest Water Loss and Storage Quality of Nine Pepper (Capsicum) Cultivars. HortScience, 29, 191-193.

[69] Díaz-Pérez, J.C., Muy-Rangel, M.D. and Mascorro, A.G. (2007) Fruit Size and Stage of Ripeness Affect Postharvest Water Loss in Bell Pepper Fruit (Capsicum annuum L.). Journal of the Science of Food and Agriculture, 87, 68-73. http://dx.doi.org/10.1002/jsfa.2672

[70] Tapia, M.R., Gutierrez-Pacheco, M.M., Vazquez-Armenta, F.J., Aguilar, G.A.G., Zavala, J.F.A., Rahman, M.S. and Siddiqui, M.W. (2015) Washing, Peeling and Cutting of FreshCut Fruits and Vegetables. In: Siddiqui, M.W. and Rahman, M.S., Eds., Minimally Processed Foods, Springer, Berlin, 57-78. http://dx.doi.org/10.1007/978-3-319-10677-9_4

[71] Cunha, A.G. (1991) Nova Fronteira Etymological Dictionary of the Portuguese Language [Dicionário Etimológico Nova Fronteira da Língua Portuguesa]. Nova Fronteira, Rio de Janeiro.

[72] Hasegawa, S. and Miyake, M. (1996) Biochemistry and Biological Functions of Citrus Limonoids. Food Reviews International, 12, 413-435. http://dx.doi.org/10.1080/87559129609541089

[73] Correia, S., Gonçalves, B., Aires, A., Silva, A., Ferreira, L., Carvalho, R., Fernandes, H., Freitas, C., Carnide, V. and Silva, A.P. (2016) Effect of Harvest Year and Altitude on Nutritional and Biometric Characteristics of Blueberry Cultivars. Journal of Chemistry, 2016, Article ID: 8648609. http://dx.doi.org/10.1155/2016/8648609

[74] Magiorkinis, E., Beloukas, A. and Diamantis, A. (2011) Scurvy: Past, Present and Future. European Journal of Internal Medicine, 22, 147-152. http://dx.doi.org/10.1016/j.ejim.2010.10.006

[75] Trippe, B.S., Barrentine, L.W., Curole, M.V. and Tipa, E. (2016) Nutritional Management of Patients with Diabetic Peripheral Neuropathy with L-Methylfolate-MethylcobalaminPyridoxal-5-Phosphate: Results of a Real-World Patient Experience Trial. Current Medical Research \& Opinion, 32, 219-227. http://dx.doi.org/10.1185/03007995.2015.1103215

[76] Siegel, B.V. (1993) Vitamin C and the Immune Response in Health and Disease. In: Klurfeld, D.M., Ed., Nutrition and Immunology, Springer, New York, 167-196. 
http://dx.doi.org/10.1007/978-1-4615-2900-2_8

[77] Moser, M.A. and Chun, O.K. (2016) Vitamin C and Heart Health: A Review Based on Findings from Epidemiologic Studies. International Journal of Molecular Sciences, 17, 1328. http://dx.doi.org/10.3390/ijms17081328

[78] Unlu, A., Kirca, O., Ozdogan, M. and Nayır, E. (2016) High-Dose Vitamin C and Cancer. Journal of Oncological Science, 1, 10-12. http://dx.doi.org/10.1016/j.jons.2015.11.010

[79] Van der Reest, J. and Gottlieb, E. (2016) Anti-Cancer Effects of Vitamin C Revisited. Cell Research, 26, 269-270. http://dx.doi.org/10.1038/cr.2016.7

[80] Ayala-Zavala, J.F., Vega-Vega, V., Rosas-Domínguez, C., Palafox-Carlos, H., Villa-Rodriguez, J.A., Siddiqui, M.W., Dávila-Aviña, J.E. and González-Aguilar, G.A. (2011) Agro- Industrial Potential of Exotic Fruit Byproducts as a Source of Food Additives. Food Research International, 44, 1866-1874. http://dx.doi.org/10.1016/j.foodres.2011.02.021

[81] Cayupán, Y.S.C., Ochoa, M.J. and Nazareno, M.A. (2011) Health-Promoting Substances and Antioxidant Properties of Opuntia sp. Fruits. Changes in Bioactive-Compound Contents during Ripening Process. Food Chemistry, 126, 514-519.

http://dx.doi.org/10.1016/j.foodchem.2010.11.033

Submit or recommend next manuscript to SCIRP and we will provide best service for you:

Accepting pre-submission inquiries through Email, Facebook, LinkedIn, Twitter, etc. A wide selection of journals (inclusive of 9 subjects, more than 200 journals)

Providing 24-hour high-quality service

User-friendly online submission system

Fair and swift peer-review system

Efficient typesetting and proofreading procedure

Display of the result of downloads and visits, as well as the number of cited articles

Maximum dissemination of your research work

Submit your manuscript at: http://papersubmission.scirp.org/

Or contact fns@scirp.org 